\title{
Primary Afferent Synapses on Developing and Adult Renshaw Cells
}

\author{
George Z. Mentis, ${ }^{2}$ Valerie C. Siembab, ${ }^{1}$ Ricardo Zerda, ${ }^{1}$ Michael J. O'Donovan, ${ }^{2}$ and Francisco J. Alvarez ${ }^{1}$ \\ ${ }^{1}$ Department of Neurosciences, Cell Biology, and Physiology, Wright State University, Dayton, Ohio 45435, and 2Laboratory of Neural Control, National \\ Institute of Neurological Disorders and Stroke, National Institutes of Health, Bethesda, Maryland 20892
}

The mechanisms that diversify adult interneurons from a few pools of embryonic neurons are unknown. Renshaw cells, Ia inhibitory interneurons (IaINs), and possibly other types of mammalian spinal interneurons have common embryonic origins within the V1 group. However, in contrast to IaINs and other V1-derived interneurons, adult Renshaw cells receive motor axon synapses and lack proprioceptive inputs. Here, we investigated how this specific pattern of connectivity emerges during the development of Renshaw cells. Tract tracing and immunocytochemical markers [parvalbumin and vesicular glutamate transporter 1 (VGLUT1)] showed that most embryonic (embryonic day 18) Renshaw cells lack dorsal root inputs, but more than half received dorsal root synapses by postnatal day 0 (P0) and this input spread to all Renshaw cells by P10-P15. Electrophysiological recordings in neonates indicated that this input is functional and evokes Renshaw cell firing. VGLUT1-IR bouton density on Renshaw cells increased until P15 but thereafter decreased because of limited synapse proliferation coupled with the enlargement of Renshaw cell dendrites. In parallel, Renshaw cell postsynaptic densities apposed to VGLUT1-IR synapses became smaller in adult compared with P15. In contrast, vesicular acetylcholine transporter-IR motor axon synapses contact embryonic Renshaw cells and proliferate postnatally matching Renshaw cell growth. Like other V1 neurons, Renshaw cells are thus competent to receive sensory synapses. However, after P15, these sensory inputs appear deselected through arrested proliferation and synapse weakening. Thus, Renshaw cells shift from integrating sensory and motor inputs in neonates to predominantly motor inputs in adult. Similar synaptic weight shifts on interneurons may be involved in the maturation of motor reflexes and locomotor circuitry.

Key words: spinal cord; development; proprioceptive; interneurons; recurrent inhibition; motoneuron

\section{Introduction}

Spinal cord circuits emerge during postnatal maturation from a dynamic set of immature synapses and embryonic neurons. Although these give rise to interneuronal circuits that have critical roles in the generation of motor output, little is known about their development. Currently, adult spinal interneurons are classified according to their synaptic inputs and their ability to modulate motoneuron firing (Jankowska, 1992, 2001). Therefore, the mechanisms that select specific synaptic inputs on interneurons are of key interest. Until recently, progress in this area has been hampered by the absence of markers to identify interneuron classes during development and the lack of a coherent framework to group developing interneurons into consistent lineages. New advances in understanding the embryonic origin of spinal interneurons and circuits promise rapid progress in this field.

Recent studies characterized different sets of spinal interneu-

Received July 11, 2006; revised Nov. 9, 2006; accepted Nov. 14, 2006.

This work was supported by National Institutes of Health Grant NS047357 (F.J.A.) and the National Institute of Neurological Disorders and Stroke intramural program (G.Z.M and M.J.O'D.). We thank Dr. Timothy Cope for comments on a previous version of this manuscript and Drs. Thomas Jessell and Julia Kaltschmidt from Columbia University for providing paraformaldehyde perfusion-fixed spinal cords from Er81 animals for this study.

Correspondence should be addressed to Francisco J. Alvarez, Department of Neurosciences, Cell Biology, and Physiology, Wright State University, 3640 Colonel Glenn Highway, Dayton, $\mathrm{OH}$ 45435. E-mail: francisco.alvarez@wright.edu.

D01:10.1523/JNEUROSCI.2945-06.2006

Copyright $\odot 2006$ Society for Neuroscience $\quad$ 0270-6474/06/2613297-14\$15.00/0 rons according to their embryonic origin (Jessell, 2000; Goulding et al., 2002). Subsequent work revealed that specific subclasses of ventral inhibitory interneurons, including Renshaw cells and putative Ia inhibitory interneurons (IaINs), develop from one embryonic group, named V1 (Sapir et al., 2004; Alvarez et al., 2005). Despite this shared embryonic origin, each interneuron subtype differs in its pattern of synaptic connections in the adult. IaINs receive input from Ia muscle afferents and mediate reciprocal inhibition between antagonistic motor pools, but they lack direct input from motoneurons (Eccles et al., 1956). In contrast, Renshaw cells mediate recurrent inhibition of homonymous and synergistic motoneurons and have been assumed to lack monosynaptic input from primary afferents (Renshaw 1946; Eccles et al., 1954). It is not known how these specific patterns of synaptic connectivity arise on distinct interneuron classes. Interestingly, a novel inhibitory interneuron with convergent inputs from primary sensory afferents and motor axons was described in the embryonic chick spinal cord (Wenner and O'Donovan, 1999). Although the adult connectivity of chick interneurons is unknown, this observation raises the possibility that adult interneurons may acquire their mature pattern of connectivity by loss/ weakening and/or gain/strengthening of specific synaptic inputs during development. Functional elimination of synaptic inputs plays important roles in shaping adult connectivity in many parts of the nervous system (Crepel et al., 1976; Shatz, 1983; Katz and 
Shatz, 1996; Katz and Crowley, 2002; Kim and Kandler, 2003) and in motoneuron projections to muscle (Brown et al., 1976; Lichtman and Colman, 2000), but its role determining patterns of synaptic connections in spinal interneurons is unclear.

We analyzed primary afferent inputs on Renshaw cells during development and compared them with motor axon inputs. Using tract tracing, immunocytochemistry, and electrophysiology, we found that neonatal Renshaw cells receive functional convergent inputs from dorsal (sensory) and ventral (motor) roots. Both inputs proliferate on Renshaw cells during the early postnatal period. Thereafter, dorsal root synapses diminish in density and size, whereas motor axon synapses continue to proliferate. This differential proliferation of motor and sensory inputs appears to be one of the mechanisms that establish the mature pattern of Renshaw cell connectivity.

Parts of this work have been published previously in abstract form (Mentis et al., 2004).

\section{Materials and Methods}

All animal procedures were performed according to National Institutes of Health (NIH) guidelines and reviewed by the local Laboratory Animal Use Committee at Wright State University and at NIH.

Dorsal root and ventral root tracing in the embryonic and neonatal spinal cord. Fluorescent dextrans (Invitrogen, Carlsbad, CA) were used to trace primary sensory afferent axons and motor axon recurrent collaterals in neonatal and embryonic mouse spinal cords. Embryonic day 18 (E18) embryos were removed from pregnant mice $(n=2)$ anesthetized with halothane, placed in cold artificial CSF $(\mathrm{ACSF})\left(\sim 4^{\circ} \mathrm{C}\right)$, and decapitated, and their spinal cords were dissected free. Mice of ages postnatal day 0 (P0) $(n=4), \mathrm{P} 4 / \mathrm{P} 5(n=6), \mathrm{P} 10(n=6)$, and P15 $(n=5)$ (SwissWebster) were also deeply anesthetized (Nembutal, $50 \mathrm{mg} / \mathrm{kg}$, i.p.), and the spinal cords were quickly removed after decapitation. Dissections were performed in chilled $\left(5-10^{\circ} \mathrm{C}\right)$, modified ACSF $\left(95 \% \mathrm{O}_{2}, 5 \% \mathrm{CO}_{2}\right)$, containing low- $\mathrm{Ca}^{2+}(0.1 \mathrm{~mm})$, high- $\mathrm{Mg}^{2+}(2 \mathrm{~mm})$, and sucrose replacement of $\mathrm{Na}^{+}$. Isolated spinal cords were pinned down in a labeling chamber with a Sylgard base and superfused with cold oxygenated ACSF $\left(\sim 18^{\circ} \mathrm{C}\right)$. One dorsal and one ventral root were placed inside suction electrodes and backfilled with fluorescent dextrans (30-40 mM, 10,000 molecular weight) coupled to fluorescein (F-Dxt), Texas Red (TR-Dxt), or Cascade Blue. Labeling proceeded overnight $(\sim 16 \mathrm{~h})$, and then the spinal cord was fixed in $4 \%$ paraformaldehyde $(4 \mathrm{~h})$ in $0.01 \mathrm{~m} \mathrm{PBS}, \mathrm{pH}$ 7.4. Cryostat sections (20-40 $\mu \mathrm{m}$ thick) were immunolabeled with rabbit polyclonal antibodies against calbindin (Swant, Bellizona, Switzerland) [1:2000 dilution in PBS with 0.1\% Triton X-100 (PBS-T)] followed by donkey anti-rabbit secondaries coupled to cyanine 5 (Cy5) or Cy3 (diluted 1:50; Jackson ImmunoResearch, West Grove, PA). In some experiments, we labeled either a dorsal or ventral root with F-Dxt, and the sections were, respectively, dual immunolabeled for calbindin and vesicular glutamate transporter 1 (VGLUT1) (guinea pig polyclonal antibody, diluted 1:2000; Chemicon, Temecula, CA), calbindin, and vesicular acetylcholine transporter (VAChT) (goat polyclonal antibody, 1:1000-1: 5000; Chemicon). Immunoreactive sites were revealed with Cy5- or Cy3coupled secondary antibodies. Immunofluorescence was imaged with confocal microscopy [Fluoview FX (Olympus Optical, Tokyo, Japan), Leica TCS (Leica, Wetzlar, Germany), Fluoview FV1000 (Olympus Optical), and Zeiss (Jena, Germany) Axioscope2 FS/MOT]. For quantitation of VGLUT1 immunofluorescence in dorsal root afferents, F-Dxt varicosities were traced in the confocal optical plane of maximum F-Dxt brightness, and the average Cy3 VGLUT1-IR intensity inside the varicosity outline was measured. To obtain a background estimate, the outline was left at the same $x-y$ coordinates and moved in the $z$-axis $3 \mu \mathrm{m}$ above and below to obtain measurements in the adjacent neuropil.

Confocal analysis of VGLUT1 and VAChT densities on calbindin-IR Renshaw cells. Three to six rats (Sprague Dawley) and mice (C56BL) of each postnatal age (P0/P1, P5, P10, P15, P20, and adult, i.e., >2 months) were anesthetized with Nembutal (50 mg/kg, i.p.) and perfused transcardially with $4 \%$ paraformaldehyde in $0.1 \mathrm{~m}$ phosphate buffer. The spinal cords were removed, postfixed for 2-6 h, and cryoprotected (15\% sucrose in $0.1 \mathrm{M}$ phosphate buffer). In addition, we used spinal cords harvested from two cats. These animals were used in previous electrophysiological studies and perfused as described previously (Alvarez et al., 1997). No cats were specifically prepared for this study. Transverse sections were obtained from L4-L5 spinal cord segments on either a freezing sliding microtome $(40-50 \mu \mathrm{m})$ and processed free floating or in a cryostat ( $20 \mu \mathrm{m}$, for neonatal tissue $\mathrm{P} 0-\mathrm{P} 5)$ and processed on slides. The sections were incubated in the following primary antisera mixtures: calbindin/VGLUT1, calbindin/VAChT, and calbindin/VGLUT1/VAChT, all diluted in PBS-T as before. Immunoreactivities were detected with species-specific secondary antibodies coupled to FITC, Cy3, or Cy5 (Jackson ImmunoResearch). In some sections from E18 to P5 tissues, we combined calbindin and/or VGLUT1 antibodies with mouse monoclonal antibodies against parvalbumin (mouse monoclonal antibody, 1:2000; Swant) to immunolabel proprioceptive afferent axons. Cat spinal cord sections were dual immunolabeled against gephyrin (mouse monoclonal antibody, clone 7a, diluted 1:200; Synaptic Systems, Goettingen, Germany) and VGLUT1 (rabbit polyclonal antibody; Synaptic Systems; dilution 1:1000).

Quantitative analyses of VGLUT1-IR or VAChT-IR bouton densities were performed in $z$-series of high magnification $(60 \times, 2.5$ digital zoom, numerical aperture 1.4) confocal optical images throughout the whole cell body and proximal dendrites of randomly sampled calbindin-IR Renshaw cells. Image stacks were analyzed in Image Pro Plus (version 5.0; Media Cybernetics, Silver Spring, MD) with 3Dspace software. Calbindin immunoreactivity was threshold, and contiguous labeled somata and dendrites were "segmented" from the image to generate threedimensional (3D) reconstructions of individual Renshaw cells. Bouton contacts were identified by scrolling over rendered neuronal surfaces (in any spatial orientation) confocal planes containing VGLUT1 or VAChT immunofluorescence (see Fig. 4 B2). Contact densities per $100 \mu \mathrm{m}^{2}$ of surface were estimated for each age and cellular compartment (somata, dendrites). Estimates of soma surface areas were validated by comparing the surface 3D rendering method with estimates of surface area from approximate ellipsoids of similar maximum and minimum diameters. We found no significant differences between somata surfaces estimated with each method (data not shown). Conversely, surface estimates of dendritic segments can be significantly affected by errors in thickness estimates attributable to variable dendritic immunofluorescence. Thus, dendritic contacts were estimated as both surface densities (number of boutons per $100 \mu \mathrm{m}^{2}$ ) and linear densities (number of boutons per 10 $\mu \mathrm{m}$ length). Linear densities are independent of surface estimate errors or developmental changes in surface area per unit of dendritic length. There were no differences between data analyzed as linear or surface densities (data not shown). For simplicity, we chose to present all data as surface densities in the confocal analysis. Contact densities were compared across ages for each species and cellular compartment (soma, dendrites) using one-way ANOVA (SigmaStat; Systat Software, Port Richmond, CA). Significance was set at $p<0.05$. If significant differences were revealed, pairwise comparisons were tested using post hoc Tukey's tests.

Neurolucida analysis of distal dendrites in matured calbindin-IR Renshaw cells. Confocal microscopy analyses of dendrites were limited by the small fields imaged at the magnification necessary $(60 \times, 2.5$ digital zoom) to unequivocally identify contacts on Renshaw cell surfaces. Decreased calbindin immunofluorescence with dendritic distance or in neonates further reduced the dendritic lengths analyzed. Thus, only the proximal $20-50 \mu \mathrm{m}$ (depending on age) of dendrite was analyzed. To determine whether inputs become more distally located later in development, preparations were made to investigate more distal dendrite segments using a neuron tracing system (Neurolucida; MicroBrightField, Colchester, VT). For this purpose, P15, P20, and adult rat spinal cord sections were processed for dual chromogen immunohistochemistry (Alvarez et al., 1999). Briefly, sections were immunolabeled with guinea pig anti-VGLUT1 (diluted 1:5000 in PBS-T; Chemicon) or goat antiVAChT (diluted 1:10,000 in PBS-T; Chemicon), and immunoreactive sites were revealed using avidin-biotin complex (ABC)-peroxidase protocols (guinea pig ABC kits; Vector Laboratories, Burlingame, $\mathrm{CA}$ ) and reacted with diaminobenzidine (DAB) $\left(0.02 \% \mathrm{DAB}\right.$ and $0.01 \% \mathrm{H}_{2} \mathrm{O}_{2}$ 
diluted in $0.05 \mathrm{~m}$ Tris buffer, $\mathrm{pH}$ 7.6). The DAB reaction product was silver intensified according to Sassoe-Pognetto et al. (1994) to obtain a black precipitate. Then ABC peroxidase for calbindin immunolabeling (diluted 1:2000 in PBS-T; Swant) was performed, and the DAB reaction was left as a brown precipitate without intensification (see Fig. $4 F-I$ ). A sample of neurons with extensive dendritic calbindin immunolabeling was obtained for each age, and their somata and dendrites were traced using a $100 \times$ objective in Neurolucida. VGLUT1-IR or VAChT-IR contacts were mapped on the traced and reconstructed dendrites. Individual dendrite lengths and total dendritic arbor size and complexity (number of branches and end points) were obtained from the software. Sholl analysis was used to estimate the distribution of VGLUT1-IR or VAChT-IR contacts at increasing $50 \mu \mathrm{m}$ bin increments from the cell soma. VGLUT1-IR or VAChT-IR contacts were expressed as number of contacts per $10 \mu \mathrm{m}$ of linear dendrite in each Sholl bin. Synaptic density differences in various dendrite compartments were compared between P15, P20, and adult using one-way ANOVAs, as before.

Intracellular recordings from Renshaw interneurons and extracellular recordings from ventral roots in the intact spinal cord in vitro. Fifty-one $\mathrm{P} 2-\mathrm{P} 4$ mice (Swiss-Webster) were used. The animals were decapitated, and the spinal cord was dissected free under cold $\left(\sim 12^{\circ} \mathrm{C}\right)$ ACSF (in mM: $128.35 \mathrm{NaCl}, 4 \mathrm{KCl}, 0.58 \mathrm{NaH}_{2} \mathrm{PO}_{4} \cdot \mathrm{H}_{2} 0,21 \mathrm{NaHCO}_{3}, 30$ D-glucose, 1.5 $\mathrm{CaCl}_{2} \cdot \mathrm{H}_{2} \mathrm{O}$, and $1 \mathrm{MgSO}_{4} \cdot 7 \mathrm{H}_{2} 0$ ). In some preparations, the sciatic nerve was dissected in continuity with its parent ventral and dorsal roots, and then the dorsal roots (L4-L6) were cut. The spinal cord was placed in a customized chamber perfused with ACSF $(\sim 13 \mathrm{ml} / \mathrm{min})$ and under the objective of a confocal microscope (Zeiss Axioscope 2 FS/MOT) equipped with three single-photon lasers $(488,543$, and $650 \mathrm{~nm})$ and a two-photon laser (Chameleon; Coherent, Santa Clara, CA). Interneurons were patched blindly approaching from the ventrolateral surface of the cord. Dorsal and ventral roots or the sciatic nerve were placed into suction electrodes for stimulation and/or recording. Recordings of extracellular activity from the ventral root were acquired at direct current $3 \mathrm{kHz}$, fed to analog-to-digital interface (Digidata 1320A; Molecular Devices, Palo Alto, CA), and stored in a personal computer using Clampex (version 9; Molecular Devices). Whole-cell recordings were acquired using a Molecular Devices Multiclamp 700A. Intracellular and extracellular recordings were sampled at $10 \mathrm{kHz}$, and both types of recording were analyzed off-line using Clampfit (Molecular Devices). Whole-cell patch electrodes had internal tip diameters between 1 and $1.5 \mu \mathrm{m}$ and average resistance of $6.5 \pm 1.7 \mathrm{M} \Omega$. The intracellular solution contained (in $\mathrm{mm}$ ): $10 \mathrm{NaCl}, 130 \mathrm{~K}$-gluconate, $10 \mathrm{HEPES}, 11 \mathrm{EGTA}, 1 \mathrm{MgCl}_{2}, 0.1 \mathrm{CaCl}_{2}$, and $1 \mathrm{Na}_{2} \mathrm{ATP}$. On the day of the experiment, $\mathrm{Na}_{2} \mathrm{ATP}$ was added to the solution, and the $\mathrm{pH}$ was adjusted to 7.2-7.3 with KOH. Alexa 488 or 568 hydrazide (final concentration of $90 \mu \mathrm{M}$ ) was sometimes added to the intracellular solution to label recorded cells (final intracellular solution of 305-309 mOsm). Motor axon stimulation was performed using suction electrodes attached to ventral roots or to the sciatic nerve several millimeters from the cord surface. Nineteen cells were identified as Renshaw cells by their responses to motor axon stimulation and maintained at resting potentials more negative than $-45 \mathrm{mV}$ (mean $\pm \mathrm{SD},-52.4 \pm$ $4.5 \mathrm{mV}$; range, -46.1 to $-65.2 \mathrm{mV}$ ), and, of these, 12 were used for analysis of sensory inputs. Some of these cells were also analyzed in a previous paper (Mentis et al., 2005). Off-line analysis was performed by averaging several traces (usually three to five trials). Statistical analysis was performed using either one-way ANOVA or $t$ tests (SigmaStat). The following drugs were used: CNQX (10 $\mu \mathrm{M})$, APV (100 $\mu \mathrm{M})$, mecamylamine (50 $\mu \mathrm{M})$, dihydro- $\beta$-erythroidine $(\mathrm{dH} \beta \mathrm{E})(50 \mu \mathrm{M})$, and atropine $(5 \mu \mathrm{M})$. All were obtained from Sigma (St. Louis, MO).

Electron microscopy immunocytochemistry and analysis. For electron microscopy, P15, P20, and adult rats (Sprague Dawley; $n=3$ at each age) were anesthetized and perfused transcardially with $4 \%$ paraformaldehyde and glutaraldehyde (variable concentrations, $0.25,0.5$, or $2 \%$ ). Spinal cords were postfixed for $4 \mathrm{~h}$. Most samples analyzed were from tissue fixed with $0.5 \%$ glutaraldehyde. Vibratome 50 - to $100-\mu$ m-thick sections were blocked with $1 \% \mathrm{NaBH}_{4}$ in PBS for $1 \mathrm{~h}$ and incubated overnight with a guinea pig anti-VGLUT1 (1:500; Chemicon) and a mouse anticalbindin antibody (1:500; Swant) diluted in PBS. The following day, calbindin-immunoreactive sites were revealed with immunogold silver techniques and VGLUT1 immunoreactivity with ABC-peroxidase methods. Sections were first incubated with goat anti-rabbit antibodies coupled to $1.4 \mathrm{~nm}$ gold particles and then amplified with HQ silver enhancement (Nanoprobes, Yaphank, NY). Thereafter, VGLUT1-IR was revealed using $\mathrm{ABC}$-peroxidase kits (Vector Laboratories) and reacted with $0.02 \% \mathrm{DAB}$ and $0.01 \% \mathrm{H}_{2} \mathrm{O}_{2}(5 \mathrm{~min})$, and the reaction product was silver intensified (Sassoe-Pognetto et al., 1994). Silver amplification produces a fine particulate precipitate over the DAB labeling that allows more accurate identification of immunolabeled structures in contrasted ultrathin sections. The sections were washed overnight, osmicated (20 $\min$ in $0.2 \% \mathrm{OsO}_{4}$ in $0.1 \mathrm{M} \mathrm{PB}$ ), dehydrated, and flat embedded in EponAraldite resin. Ultrathin sections were counterstained with uranyl acetate and lead citrate and examined in a Phillips (Aachen, Germany) 208S electron microscope at $70 \mathrm{kV}$. Calibrated images were obtained either digitally (BioScan model 792; Gatan, Pleasant, PA) or photographically (EM $4 \times 5$ negatives) and scanned at $1200 \mathrm{dpi}$ (Flextight 848; Imacom, Copenhagen, Denmark).

Digital images were analyzed using Image Pro Plus. The average sizes of the presynaptic bouton, the presynaptic active zone, the apposition area, and the postsynaptic density (PSD) were estimated for samples of VGLUT1-IR synapses on calbindin-IR dendrites or on large dendrites in lamina IX (LIX) (likely from motoneurons). These synaptic parameters were compared across ages using one-way ANOVAs (SigmaStat); $t$ tests were used for pairwise comparisons between VGLUT1-IR boutons presynaptic to each postsynaptic target of the same age. Significance for all statistical tests was set at $p<0.05$.

\section{Results \\ Primary afferent and motor axon synaptic markers in the developing spinal cord}

Several anatomical methods were used to identify primary afferent and motor axon contacts on developing Renshaw cells. Each approach was optimal during specific overlapping developmental periods; thus, conclusions on input densities are based on the best methodological combinations at different postnatal times. In addition, expression of the various immunocytochemical markers used also underwent developmental maturation. We first briefly describe the efficacy of the different labeling methods and developmental changes in marker expression to clarify their use during development and provide information on synapse structural maturation for each input. Tract tracing with fluorochrome-conjugated dextrans from either dorsal or ventral roots and immunolabeling for parvalbumin, VGLUT1, and VAChT were used to analyze sensory and motor axon synaptic varicosities on embryonic (E18), postnatal (P0/P1, P4/P5, P10, $\mathrm{P} 15$, and P20), and adult Renshaw cells in the lumbar 5 segment (Figs. 1,2). Calbindin immunoreactivity clearly labels the cluster of Renshaw cells located in the ventralmost regions of LVII and LIX in embryonic, neonatal, and adult spinal cords of mice and rats (Figs. 1, 2) (Carr et al., 1998; Geiman et al., 2000; Sapir et al., 2004). F-Dxt, TR-Dxt, or Cascade Blue-conjugated dextran tracing was used from E18 to P15 (Fig. 1A, 2A-D). The efficiency of Dxt tracing from ventral or dorsal roots decreased sharply at P15. Dxt transport might be compromised in older spinal cords because their larger size and extent of myelination impedes adequate oxygenation under in vitro conditions and during the necessary long transport times $(>16 \mathrm{~h})$. In addition, expansion of sensory afferent rostrocaudal projections result in age-related decreases in the proportion of sensory synapses labeled from individual dorsal roots at any given segment. As an alternative marker, we used parvalbumin immunoreactivity to specifically label proprioceptive axons (supplemental Fig. S1, available at www.jneurosci.org as supplemental material) (Arber et al., 2000). The correlation between parvalbumin labeling and Dxt tracing was very good in embryonic and early postnatal spinal 
cords. However, at approximately P10, spinal interneurons upregulate parvalbumin expression, and, thereafter, parvalbumin-IR axons cannot be specifically ascribed a primary afferent origin. In conclusion, in vitro dextran tracing from dorsal roots and parvalbumin immunolabeling are effective methods to specifically label large numbers of primary afferent inputs until P10.

VGLUT1 and VAChT were found to be highly specific presynaptic markers for, respectively, sensory afferent and motor axon synapses on both developing and adult Renshaw cells. Dorsal root Dxt-filled varicosities or parvalbumin-IR sensory axons in spinal cords from postnatal animals always contained bright VGLUT1-IR clusters (Fig. 2C) (supplemental Fig. S1, available at www.jneurosci.org as supplemental material). Moreover, VGLUT1-IR boutons are not present on calbindin-IR Renshaw cells in P15 Er81-/- mutants, confirming their primary afferent origin (supplemental Fig. S2, available at www. jneurosci.org as supplemental material). Surprisingly, VGLUT1-IR was undetectable inside Dxt-filled or parvalbumin-immunolabeled primary afferent axons in the embryonic spinal cord. At P0/P1, many Dxt-filled or parvalbumin-immunolabeled varicosities contained clear VGLUT1-IR clusters, and, by $\mathrm{P} 4 / \mathrm{P} 5$, there was an excellent correlation between ventral horn primary afferent varicosities (Dxt-filled or parvalbumin-IR) and VGLUT1-IR punctae. Average VGLUT1 immunofluorescence intensity inside Dxt-filled primary afferent varicosities at $\mathrm{P} 0$ was $1638 \pm 481(n=50$; average $\pm \mathrm{SD}$, in arbitrary units from 24 bit images, i.e., max of 4095) compared with $306 \pm 180$ background. VGLUT1 immunofluorescence increased at P10 to $3399 \pm 539$ units $(n=50 ; p<0.001, t$ test $)$, whereas background levels remained the same (357 \pm 199$)$. In parallel, Dxt-labeled varicosities doubled in size from an apparent area of $0.71 \pm 0.33 \mu \mathrm{m}^{2}$ at P0 to $1.30 \pm 0.52 \mu \mathrm{m}^{2}$ at P10 (average $\pm \mathrm{SD} ; p<0.001, t$ test). P15 Dxt-filled primary afferent varicosities contained larger and brighter VGLUT1-IR clusters (Fig. 2C). VGLUT1-IR cluster sizes were not different at P15 $\left(5.1 \pm 0.3 \mu \mathrm{m}^{2}\right), \mathrm{P} 20\left(5.3 \pm 0.3 \mu \mathrm{m}^{2}\right)$, and adult $\left(5.9 \pm 0.3 \mu \mathrm{m}^{2}\right.$; $n=50$ clusters at each age; $p=0.177$, one-way ANOVA). VGLUT1 immunofluorescence intensity was very bright at these ages and saturated our imaging system at the acquisition sensitivities used to efficiently detect most VGLUT1-IR punctae at P0. In summary, presynaptic VGLUT1-IR vesicle clusters are not detectable in embryonic dorsal root sensory afferents, these clusters were first detected at P0, and, thereafter, they became bigger and brighter, suggesting rapid maturation of the presynaptic machinery up to P15.

VAChT-IR boutons specifically label intraspinal motor axon collateral synapses on Renshaw cells as suggested by their location, size, and neurochemical phenotype (Alvarez et al., 1999) and their disappearance in adult superoxide dismutase 1-mutant animals undergoing motor axon degeneration (FitzSimons et al., 2006). Some VAChT-IR contacts on Renshaw cells were also ret- rogradely labeled with fluorochrome Dxts from ventral roots (Fig. 2D) (Mentis et al., 2005). In contrast to VGLUT1, VAChT-IR clusters are already abundant in the ventral horn at E18 (Fig. 1A), but, similar to VGLUT1, VAChT-IR clusters undergo significant postnatal maturation in size and immunofluorescence brightness. Therefore, VAChT-IR synapses, likely from motor axon collaterals, are well established in embryo before primary afferents contact Renshaw cells. Postnatally, they further mature the presynaptic machinery similar to sensory afferent synapses.

\section{Postnatal Renshaw cells receive convergent inputs from} dorsal root sensory afferent and ventral root motor axon synapses

Almost all mouse and rat calbindin-IR neurons in the Renshaw cell area of E18, P0/P1, P5, P10, P15, P20, and adult spinal cords ( $\sim 100 \mu \mathrm{m}$ ventral most regions) received either VAChT-IR bouton contacts (Figs.1C,D, 2D) and/or contacts from varicosities retrogradely from ventral roots (Fig. $2 A, B, D$ ). Based on VAChT-IR contacts, we concluded that motor axon inputs have already spread to the whole Renshaw cell population in E18 mouse embryos. Unfortunately, only a proportion of VAChT-IR contacts were retrogradely labeled from ventral roots with any of the three fluorochrome-conjugated Dxts used. Intraspinal motor axon collaterals were especially difficult to identify in embryonic spinal cords despite excellent retrograde labeling. Thus, we could 

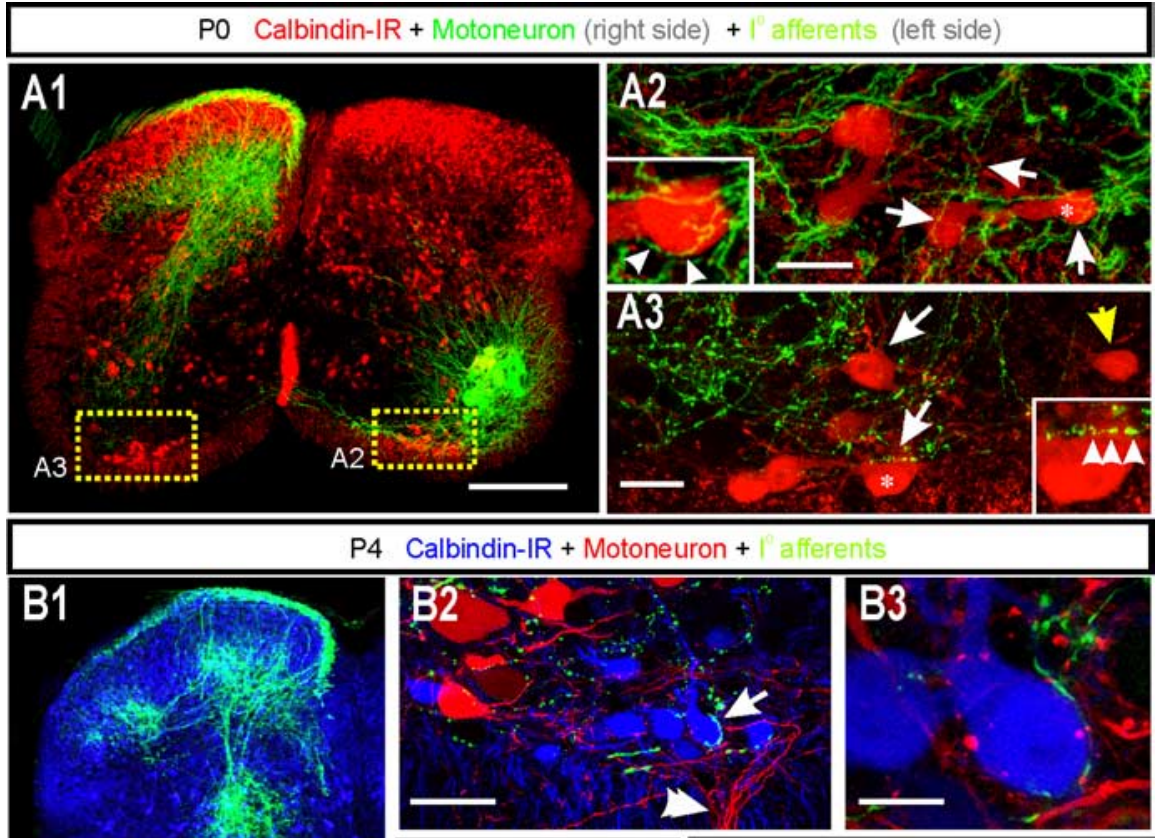

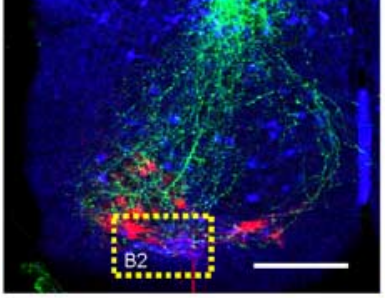

E

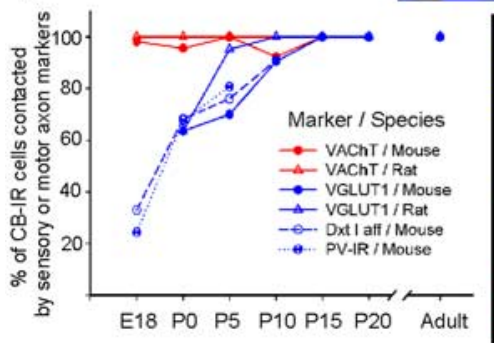

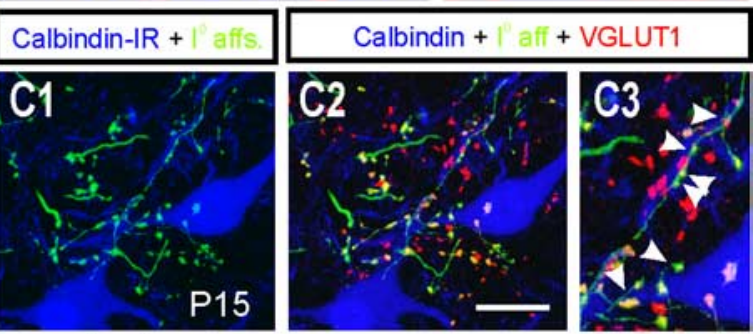

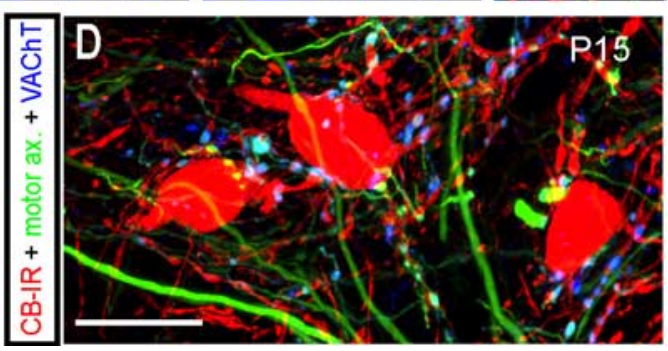

Figure 2. Dorsal root and motor axon inputs on postnatal Renshaw cells. A1, P0 mouse lumbar 5 spinal cord showing primary afferent axons (left) and motoneurons (right) filled with F-Dxt applied to dorsal or ventral roots and superimposed on calbindin immunofluorescence (red, Cy3). The Renshaw cell areas are boxed and shown at higher magnification in $\mathbf{A}$ and $\mathbf{A 3}$. A2, Retrogradely F-Dxt-filled motoneurons dendrites and axons (arrows) around calbindin-IR Renshaw cells (red). Motor axon collaterals are distinguished by their non-tapering and varicose-studded fine processes branching frequently at right angles. Motor axon recurrent collaterals contact neonatal calbindin-IR Renshaw cells. Contacts onto the cell marked with an asterisk are shown at higher magnification in the inset. $\mathbf{A 3}$, High-magnification image of F-Dxt-filled primary afferents in contact with calbindin-IR Renshaw cells (white arrows in $\boldsymbol{A}$; inset shows cell with asterisk at higher magnification). At this age, a few Renshaw cells did not receive any F-Dxt dorsal root axon contacts (i.e., yellow arrow in $\boldsymbol{A}$ ). These were generally located more medially in the Renshaw cell pool. B1, Confocal image of a P4 hemicord containing primary afferent sensory fibers labeled with F-Dxt (green) and motoneurons and motor axons labeled with TR-Dxt (red). The section was also immunolabeled with calbindin antibodies (blue, (y5). $\boldsymbol{B 2}$, Higher-magnification image of the area boxed in $\boldsymbol{B}$. Renshaw cells are positioned at the exit of motor axons (double arrowhead). Motoneurons (red, TR-Dxt) and calbindin-IR Renshaw cells (blue, Cy5) are both surrounded and contacted by primary afferent axons (F-Dxt, green, arrow). Renshaw cells are also contacted by motor axon varicosities (red; TR-Dxt). B3, Highmagnification image of the Renshaw cell indicated with an arrow in $\mathbf{B} 2$ and receiving convergent contacts from motor axon (red) and primary afferent (green) varicosities. C1-C3, High-magnification images from a P15 spinal cord triple labeled to show primary afferents (F-Dxt from dorsal roots), VGLUT1-IR varicosities (red, Cy3), and calbindin-IR Renshaw cells (blue, Cy5). Primary afferent axonal varicosities contact P15 Renshaw cells on cell bodies and dendrites (C1). Superimposition of VGLUT1-IR (red) shows that all primary afferent varicosities, including those in contact with Renshaw cells, contain VGLUT1 immunoreactivity. VGLUT1-IR contacts are shown at higher magnification in C3. Arrowheads point to VGLUT1-IR dorsal root afferent varicosities (yellow) in contact with a Renshaw cell calbindin-IR dendrite (blue). D, High-magnification image of calbindin-IR Renshaw cells at the motor axon exit zone (motor axons retrogradely labeled with F-Dxt from the ventral root) and superimposed with VAChT-IR (blue, (y5). This region contains a high density of retrogradely labeled motor axon recurrent collateral with many varicosities. Motor axon varicosities contain VAChT-IR (green plus blue) and frequently contact calbindin-IR Renshaw cells. $E$, Percentages of calbindin-IR (CB-IR) cells receiving at least one contact from each of the markers used to identify dorsal and ventral root inputs. not obtain reliable estimates of motor axon inputs based on retrograde Dxt labeling.

In contrast to motor axons, only 24 $33 \%$ of E18 calbindin-IR mouse Renshaw cells were contacted by parvalbumin-IR processes or Dxt-filled sensory axons, respectively (at least one contact on somata and/or dendrites). These contacts lacked detectable VGLUT1. However, at birth (P0/P1), $60-64 \%$ of mouse or rat Renshaw cells received contacts (usually multiple) from Dxt-filled dorsal root axons, parvalbumin-IR varicosities, and/or VGLUT1-IR clusters (Fig. 2 A). The number of Renshaw cells contacted by Dxtfilled, parvalbumin-IR, or VGLUT1-IR primary afferent varicosities increased steadily in the postnatal mouse or rat spinal cord (Fig. $2 B, C, E$ ). Estimates among different markers and species were in very good agreement at all ages analyzed (numerical data in supplemental Fig. S3, available at www.jneurosci.org as supplemental material). All (100\%) calbindin-IR Renshaw cells received contacts from VGLUT1-IR primary afferents by P10 in rat and by P15 in mouse. The presence of primary afferent inputs on adult Renshaw cells in rodents contrasts with the current view that Renshaw cells lack this input. Because this conclusion is derived from cat spinal cord in vivo electrophysiological recordings, we investigated further whether VGLUT1-IR contacts are present on adult cat Renshaw cells. Gephyrin-immunolabeling was used for Renshaw cell identification in the adult cat (Alvarez et al., 1997) because calbindin is only rather weakly expressed in just a few cat Renshaw cells (44.6\%; $n=50)$ (Carr et al., 1998). All cat Renshaw cells $(n=15)$ displayed VGLUT1-IR contacts (Fig. 3). VGLUT1-IR contact density was twofold to fourfold larger on cat Renshaw cell somata compared, respectively, with mouse and rat.

In summary, motor axons synapse on embryonic, postnatal, and adult Renshaw cells as expected, but, in addition, a significant primary afferent input is organized over neonatal Renshaw cells. During the

$\leftarrow$

$y$-Axis indicates the percentage of cells contacted by each marker. The characteristics of these samples and methods are explained in supplemental Figure $S 3$ (available at www. jneurosci.org as supplemental material). Almost all calbindin-IR Renshaw cells receive VAChT-IR contacts (motor axon) in embryo. In contrast, dorsal root inputs are few in embryo spreading to all Renshaw cells after birth. There was good agreement between all markers used and in both species. PV, Parvalbumin. Scale bars: A1, B1, $200 \mu \mathrm{m} ; A \mathbf{A}, A \mathbf{A}, \mathbf{D}, 20 \mu \mathrm{m}$; $B 2,40 \mu \mathrm{m} ; B 3,10 \mu \mathrm{m}$; (in C2) C1, C2, $20 \mu \mathrm{m}$. 
first postnatal week, this sensory input spreads to all Renshaw cells and, contrary to current thinking, is maintained in adult. Primary afferent VGLUT1-IR contacts on adult Renshaw cells is not species specific, because such contacts were found in mouse, rat, and cats.

VGLUT1-IR and VAChT-IR synaptic densities over Renshaw cells increase until P15 and, thereafter, VGLUT1 bouton density decreases, whereas VAChT bouton density is maintained The presence of convergent inputs from sensory and motor axons on neonatal and adult Renshaw cells contrasts with the view that motor axon inputs are the main source of excitatory input into these interneurons. One possibility is that each synaptic input displays dramatically different weights in adult. The strength of any synaptic input depends on the number of synapses, their distribution on dendrites, and the synaptic efficacy of the individual synapses. We therefore examined possible age-related changes in VGLUT1-IR bouton densities on Renshaw cells and compared them with VAChT-IR motor axon synapses. Conclusions were confirmed in rats and mice and with two different morphological analytical procedures.

Contact densities on rat and mouse calbindin-IR Renshaw cells of different ages were first analyzed in 3D reconstructions of somata and proximal dendrites obtained from series of confocal optical sections (Fig. 4A,B). One to four dendritic proximal segments were analyzed per cell. The maximum lengths of dendrites analyzed with confocal analysis was limited by age differences in dendrite immunolabeling and the relatively small field of view at the high magnifications needed for "contact" identification. On average, the farthest distance from soma analyzed at P0/P1 was $26.1 \pm 1.5 \mu \mathrm{m}( \pm \mathrm{SEM})$ in rat and $23.4 \pm 1.0 \mu \mathrm{m}$ in mouse. Progressively longer dendritic segments were analyzed at older ages, up to an average $41.0 \pm 1.4$ and $38.6 \pm 1.3 \mu \mathrm{m}$ in adult mouse and rat Renshaw cells, respectively. These correspond to $\sim 12-15 \%$ of the total calbindin-immunoreactive dendrite length analyzed later using neuronal tracing in bright field (see below). The number of contacts per reconstructed cell soma and dendritic segment was normalized by total dendritic length (linear density) or total membrane surface of somata or dendrites (surface density). Estimates of linear and surface density parallel each other. Only data on surface densities are shown (Fig. 4C-E).

The number and density of VGLUT1-IR and VAChT-IR contacts was higher on dendrites than somata. P0/P1 mouse or rat calbindin-IR Renshaw cells displayed few VGLUT1-IR bouton contacts on somata or dendrites (Fig. $4 C, D$ ), but these significantly increased at P15 and then decreased in P20 and adult $(p<$ 0.001; one-way ANOVA). Rat and mouse Renshaw cells were similar. Post hoc tests indicated that densities at P15 were significantly different to all other ages in both somata and dendrites and in both species ( $p<0.05$, post hoc Tukey's test). On dendrites, VGLUT1-IR densities increased fivefold to sevenfold from $\mathrm{P} 0$ to $\mathrm{P} 15$ and then decreased to less than half the P15 density in the adult. The number of contacts per cell body or dendrite in adult Renshaw cells was nevertheless significantly higher than at P0 in both species, indicating a net gain of VGLUT1-IR synapses.
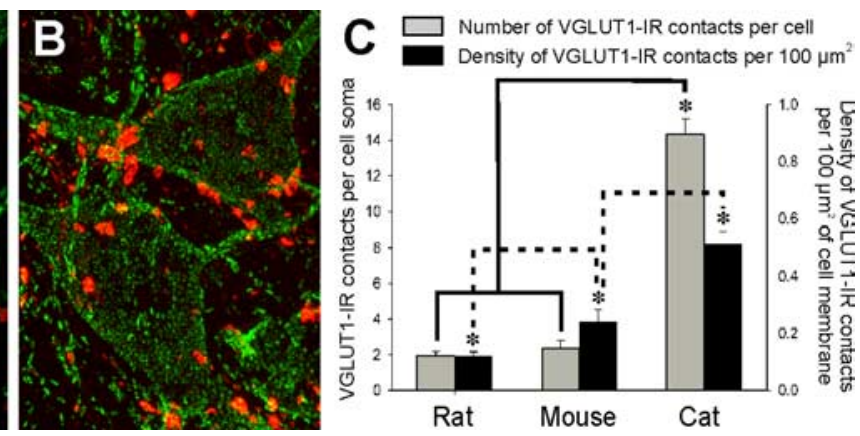

Rat Mouse Cat

Figure 3. VGLUT1-IR contacts on cat Renshaw cells. $\boldsymbol{A}, \boldsymbol{B}$, Single optical plane $(\boldsymbol{A})$ and surface reconstruction ( $\boldsymbol{B} ; 23$ optical lanes, $z$-step $=0.5 \mu \mathrm{m}$ ) of two cat Renshaw cell somata identified by the high density of large and bright gephyrin-IR clusters on detected in VGLUT1-IR contact density between rat and mouse, despite similar numbers of contacts. This difference arises because

This was reflected in generally higher synaptic densities on somata and dendrites in adult compared with P0.

The postnatal maturation of VAChT-IR contacts was analyzed on rat Renshaw cells (Fig. $4 E$ ). VAChT-IR contacts were significantly denser than VGLUT1-IR contacts at P0/P1 in both cell bodies and dendrites ( $p<0.01, t$ tests). Thereafter, VAChT-IR contact densities significantly increased from P5 to P15 in parallel to VGLUT1-IR boutons (one-way ANOVA, $p<$ 0.05). In contrast to VGLUT1, VAChT-IR contact density was maintained after P15 (P15, P20, and adult VAChT-IR contact densities were not significantly different, $p>0.05$, post hoc tests). As a result, the densities of VAChT-IR contacts on adult rat Renshaw cells somata and dendrites are significantly higher than VGLUT1 ( $p<0.001, t$ tests).

One explanation for the reduced density of VGLUT1-IR contacts after P15 is the disassembly of a proportion of synapses. Alternatively, VGLUT1-IR contacts could be redistributed over the mature dendritic arbors. To analyze more distal segments, VGLUT1-IR or VAChT-IR boutons were visualized on calbindin-immunolabeled dendritic trees using dual-color immunoperoxidase. VGLUT1-IR or VAChT-IR boutons were labeled with silver-intensified DAB (black) and calbindin immunoreactivity with non-intensified DAB (brown) (Fig. 4F-I). Contact positions were plotted in bright field over dendrites reconstructed using a computer-aided neuronal tracing system (Neurolucida). The analysis was performed in P15, P20, and adult rat spinal cord of lumbar 4 and 5 segments. Calbindin-IR Renshaw cell dendrites increased in complexity from P15 to adult. The length of individual dendrites, the size of dendritic arbors, and their branching and complexity increased from P15 to adult (Tables 1,2). Interestingly, the average number of VGLUT1-IR contacts per cell was only slightly reduced from P15 to adult (Table 1). This reduction was not statistically significant ( $p=0.173$, $t$ test). However, VGLUT1-IR overall density on dendrites (contacts per $10 \mu \mathrm{m}$ of linear dendrite) decreased by $28 \%$ ( $p<0.001, t$ test) attributable to the increased size of the dendritic arbor with age (20\% average increase of immunolabeled dendritic arbor size from P15 to adult; $p<0.05, t$ test). Sholl analyses (Fig. $4 \mathrm{~J}$ ) indicated that VGLUT1-IR contact density decreased in parallel at most distance bins from the cell body 


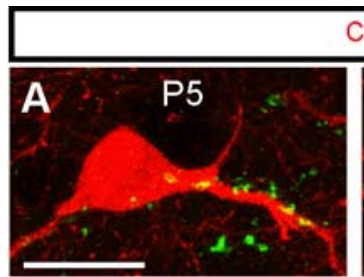

VGLUT1-IR contacts per C $100 \mu \mathrm{m}^{2}$ of membrane surface on mouse Renshaw cells
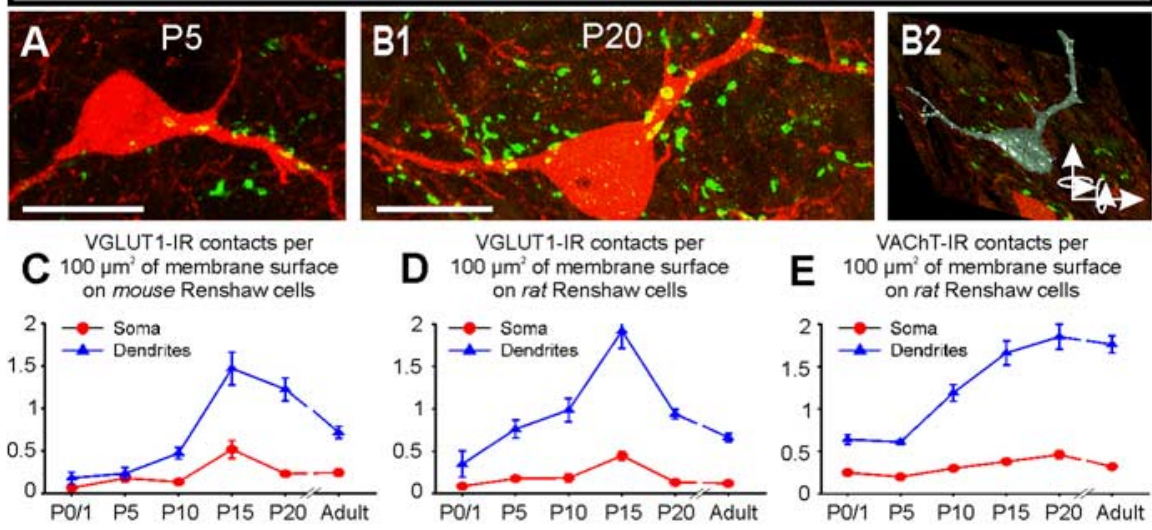

VGLUT1-IR contacts per

D $100 \mu \mathrm{m}^{2}$ of membrane surface on rat Renshaw cells

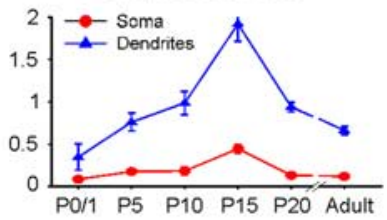
VAChT-IR contacts per E $100 \mu \mathrm{m}^{2}$ of membrane surface on rat Renshaw cells

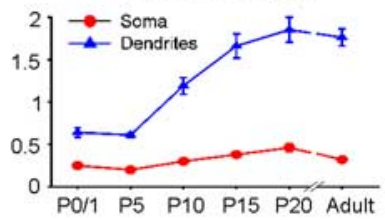

VGLUT1 (black) / calbindin (brown)
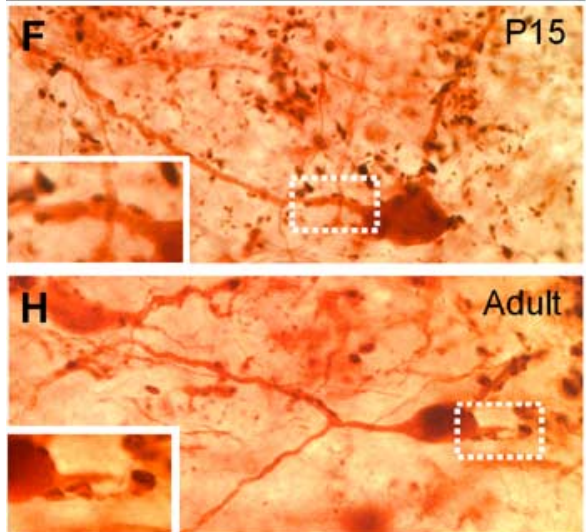

J

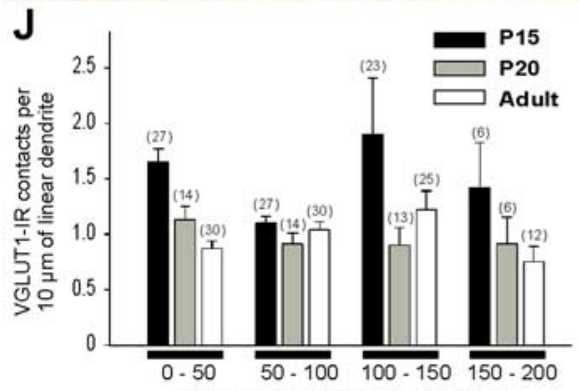

Sholl bin from center of soma $(\mu \mathrm{m})$
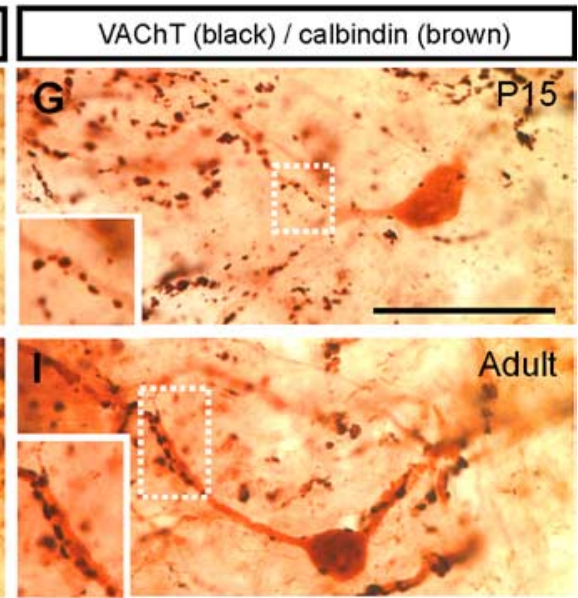

$\mathrm{K}$

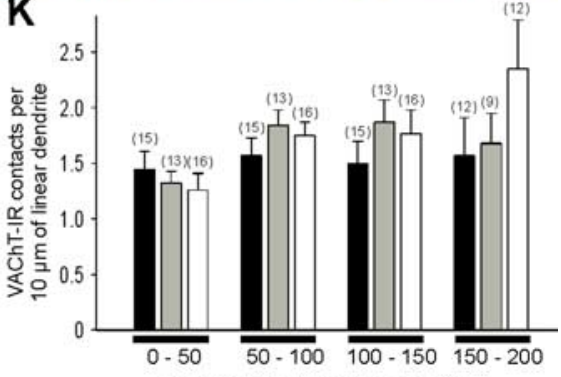

Sholl bin from center of soma $(\mu \mathrm{m})$
Figure 4. Postnatal changes in the density of VGLUT1-IR and VAChT-IR boutons contacting Renshaw cells. $A, B$, Examples of high-magnification images used in confocal analysis. In this case, several optical planes of VGLUT1-IR contacts (green, FITC) are shown on P5 (A) and P20 (B1) calbindin-IR Renshaw cells (red, Cy3). B2, 3D reconstruction and rotation of the cell shown in $\boldsymbol{B} 1$. One confocal plane is shown over the rendered surface of the cell. All optical planes containing VGLUT1-IR boutons were scanned through 3D-rendered surfaces, and rotations were used to better visualize contacts on the neuronal surface. $C, D$, Density of VGLUT1-IR contacts on the surface of postnatal calbindin-IR Renshaw cells in mouse $(\boldsymbol{C})$ and rat $(\boldsymbol{D})$. The number of contacts per $100 \mu \mathrm{m}^{2}$ of surface membrane on Renshaw cell somata (red, circles) and dendrites (blue, triangles) increase from P0/P1 to P15 and then decrease in P20 and adult in both species. Error bars indicate SEM. Both the increase from P0/P1 to P15 and the decrease at P20 were significant ( $p<0.05$, one-way ANOVA). Differences among successive ages usually did not reach significance except for P15 ( $p<0.05$, post hoc Tukey's test). $n=11-10$ Renshaw cells in, respectively, mouse and rat at P0/P1, 20-21 cells at P5, $\mathrm{P} 10$, and P15, and 30 cells in P20 and adult in each species and age. For this analysis, one mouse was used at P0 and one rat at P1, two animals of each species were used at P5, P10, and P15, and three animals of each species were used at P20 and adult. $E$, Similar density plot but for VAChT-IR contacts on Renshaw cells in the rat spinal cord. Similar to VGLUT1, VAChT-IR contact densities increased significantly from P0 to P15 in both the somatic and dendritic compartments ( $p<0.05$, one-way ANOVA). In contrast to VGLUT1-IR boutons, the densities of VAChT-IR contacts were maintained after P15 (no significant differences detected for P15, P20, and adult, one-way ANOVA). $n=10$ Renshaw cells analyzed at each age. $\boldsymbol{F}-\boldsymbol{I}$, Calbindin-immunoreactive Renshaw cells (brown reaction product, DAB) at P15 $(\boldsymbol{F}, \boldsymbol{G})$ and adult $(\boldsymbol{H}, \boldsymbol{I})$ contacted by VGLUT1-IR boutons (black, silver-intensified DAB) in $\boldsymbol{F}$ and $\boldsymbol{H}$ or VAChT-IR boutons (also in black, silver-intensified DAB) in $\boldsymbol{G}$ and $\boldsymbol{I}$. Dotted rectangles indicate regions magnified in their respective insets and showing immunoreactive contacts on Renshaw cell dendrites. Both VGLUT1-IR and VAChT-IR inputs preferentially target dendritic arbors. At P15, the densities of VGLUT1 and VAChT-IR contacts appear similar, but VGLUT1-IR contact density is reduced on adult calbindin-IR Renshaw cells. J, Sholl analysis of VGLUT1-IR contacts (per $10 \mu \mathrm{m}$ of linear dendrite) estimated in $50 \mu \mathrm{m}$ bins of increasing distance from the center of the cell body. Data from P15, P20, and adult calbindin-IR
(50 $\mu \mathrm{m}$ increments). In contrast, VAChT-IR contact density remained constant (or slightly increased) in all dendritic compartments from P15 to adult (Fig. $4 K$, Table 2) ( $p>0.05$, one-way ANOVA). VAChT-IR bouton densities were maintained during dendritic growth by a significant increase $(\sim 30 \%)$ in total number of VAChT-IR boutons from P15 to adult $(p<0.01$, one-way ANOVA). The cellular mechanisms that scale synaptic inputs to match the maturation of postsynaptic dendritic trees and neurons are presently unknown.

In summary, neonatal sensory inputs in Renshaw cells appear deselected in the adult by lack of synapse proliferation during the time of postnatal dendritic growth. As a result, the density of VGLUT1-IR sensory synapses is significantly decreased in adult Renshaw cells. Next, we investigated whether dorsal root synapses are functional on neonatal Renshaw cells.

\section{Electrophysiological identification of neonatal Renshaw cells}

Using an in vitro preparation of the mouse spinal cord, we recorded from 122 neonatal (P2-P4) neurons targeted blind with patch electrodes in the Renshaw cell area of the lumbar segments (L1 to L5) (Fig. $5 A)$. Twenty-one cells exhibited shortlatency EPSPs after motor axon stimulation; latencies were $3.6 \pm 0.7 \mathrm{~ms}$ after ventral root stimulation and $5.6 \pm 0.6 \mathrm{~ms}$ after sciatic nerve stimulation at a distance of $\sim 7-8 \mathrm{~mm}$ from the spinal cord (dorsal roots cut). We recorded similar potentials whether stimulating the ventral roots or the sciatic nerve, making it very unlikely that evoked responses were attributable to stimulus spread into the cord. Renshaw cell responses to single antidromic stimuli were graded with stimulus intensity, and, at suprathreshold levels, they evoked firing in the range of $83-122 \mathrm{~Hz}$ (Fig. 5B) (mean $\pm \mathrm{SD}, 102 \pm 14 \mathrm{~Hz} ; n=8$ ). At high frequencies of stimulation, the response

$\leftarrow$

neurons are grouped for each distance bin. The numbers in parentheses indicate the number of Renshaw cells that showed data at each distance bin. Too few dendrites/Renshaw cells provided data beyond $200 \mu \mathrm{m}$, and therefore these bins were not analyzed further. A decrease in the number of VGLUT1-IR contacts per $10 \mu \mathrm{m}$ of linear dendrite was apparent in most distance bins (except for the 50-100 $\mu \mathrm{m}$ ), indicating that there are no major shifts in VGLUT1-IR bouton distributions at different distances from the cell soma. $\boldsymbol{K}$, Similar analyses for VAChT-IR boutons. In contrast to VGLUT1-IR boutons, VACHT-IR bouton density was either maintained or had a tendency to increase at P20 and adult compared with P15. Scale bars: $\boldsymbol{A}, \boldsymbol{B}, 20 \mu \mathrm{m}$; (in $\boldsymbol{G}) \boldsymbol{F}-\boldsymbol{I}, 50 \mu \mathrm{m}$. 
Table 1. VGLUT1-IR bouton contact densities and dendritic arbors of Renshaw cells of different ages

\begin{tabular}{|c|c|c|c|c|c|c|c|c|}
\hline & $\begin{array}{l}\text { Most distal dendritic } \\
\text { point }(\mu \mathrm{m})\end{array}$ & $\begin{array}{l}\text { Average dendritic } \\
\text { length }(\mu \mathrm{m})\end{array}$ & $\begin{array}{l}\text { Average total length of } \\
\text { dendritic arbor }(\mu \mathrm{m})\end{array}$ & $\begin{array}{l}\text { Average \# of first-order } \\
\text { dendrites }\end{array}$ & $\begin{array}{l}\text { Average \# } \\
\text { of ends }\end{array}$ & $\begin{array}{l}\text { VGLUT1-IR contacts } \\
\text { per } 10 \mu \mathrm{m} \text { of } \\
\text { dendrite }\end{array}$ & $\begin{array}{l}\text { Total \# of VGLUT1 } \\
\text { contacts per cell }\end{array}$ & $n$ \\
\hline P15 & 283.90 & $131.6 \pm 8.43$ & $204.31 \pm 14.44$ & $2.04 \pm 0.19$ & $2.85 \pm 0.24$ & $1.34 \pm 0.07$ & $26.48 \pm 1.77$ & 27 \\
\hline P20 & 266.80 & $149.16 \pm 13.65$ & $210.79 \pm 14.04$ & $1.86 \pm 0.21$ & $3.00 \pm 0.31$ & $0.95 \pm 0.08$ & $19.641 \pm 1.81$ & 14 \\
\hline Adult & 320.10 & $150.29 \pm 9.86$ & $253.48 \pm 15.98$ & $2.47 \pm 0.29$ & $3.43 \pm 0.19$ & $0.97 \pm 0.05$ & $23.53 \pm 1.25$ & 30 \\
\hline
\end{tabular}

\pm indicates SEM.

Table 2. VAChT-IR bouton contact densities and dendritic arbors of Renshaw cells of different ages

\begin{tabular}{|c|c|c|c|c|c|c|c|c|}
\hline & $\begin{array}{l}\text { Most distal dendritic } \\
\text { point }(\mu \mathrm{m})\end{array}$ & $\begin{array}{l}\text { Average dendritic } \\
\text { length }(\mu \mathrm{m})\end{array}$ & $\begin{array}{l}\text { Average total length of } \\
\text { dendritic arbor }(\mu \mathrm{m})\end{array}$ & $\begin{array}{l}\text { Average \# of first-order } \\
\text { dendrites }\end{array}$ & $\begin{array}{l}\text { Average \# } \\
\text { of ends }\end{array}$ & $\begin{array}{l}\text { VAChT-IR contacts } \\
\text { per } 10 \mu \mathrm{m} \text { of } \\
\text { dendrite }\end{array}$ & $\begin{array}{l}\text { Total \# of VAChT } \\
\text { contacts per cell }\end{array}$ & $n$ \\
\hline P15 & 187.20 & $122.9 \pm 8.58$ & $188.77 \pm 15.56$ & $2.00 \pm 0.17$ & $3.00 \pm 0.35$ & $1.47 \pm 0.113$ & $27.00 \pm 2.05$ & 15 \\
\hline P20 & 191.0 & $125.54 \pm 19.45$ & $202.69 \pm 19.45$ & $2.31 \pm 0.13$ & $3.15 \pm 0.22$ & $1.72 \pm 0.18$ & $30.92 \pm 2.81$ & 13 \\
\hline Adult & 256.8 & $139.03 \pm 12.28$ & $231.88 \pm 19.99$ & $2.13 \pm 0.20$ & $3.44 \pm 0.29$ & $1.54 \pm 0.08$ & $34.63 \pm 3.09$ & 16 \\
\hline
\end{tabular}

\pm indicates SEM.

latencies showed little jitter (Fig. 5B). As expected, in three Renshaw cells tested, their responses to motor axon stimulation were greatly reduced $(78.8 \pm 8.9 \%$ of control) (Mentis et al., 2005) in the presence of cholinergic blockers (mecamylamine at $50 \mu \mathrm{M}$, $\mathrm{dH} \beta \mathrm{E}$ at $50 \mu \mathrm{M}$, and atropine at $5 \mu \mathrm{M})($ Fig. $5 F)$.

During the experiment, we injected some of recorded neurons $(n=5)$ with a fluorescent dye (Alexa 488 or 568) to visualize their morphology and axonal trajectory. Labeled cells were ventrally located, with small cell bodies and a limited dendritic tree. Their axons bifurcated in the ventral funiculus and projected both rostrally and caudally for $1.5(n=1), 2(n=2)$, or $3(n=2)$ segments and an average distance of $1093.2 \pm 145.4 \mu \mathrm{m}$ (mean \pm SEM; range, $622-1452 \mu \mathrm{m}$ ). The axons gave off collaterals throughout their length that reentered the motor pools (Fig. $5 E$ ). The extension of the visualized axons was dependent on the length of the recording and tracer filling, the longest axons corresponding with recordings of $>3 \mathrm{~h}$ duration. The intersegmental spread of axon collaterals in our sample of P2-P4 mouse Renshaw cell was longer than expected from previous work in adult animals. Renshaw cell outputs are generally distributed within one or two segments in the adult cat lumbar spinal cord (Jankowska and Smith, 1973; McCurdy and Hamm, 1994), and the principal axonal arborization is located within $500 \mu \mathrm{m}$ of the cell body in the rostral and caudal direction (van Keulen, 1979; Lagerback and Kellerth, 1985; Fyffe, 1991). However, in these studies, the main axon traveled in the ventral funiculus for up to $3 \mathrm{~mm}$ in the cranial or caudal direction, at which point the intracellular label faded and could not be followed for longer distances. This anatomical organization is not too different to the one reported here, except that, because of the shorter distances of lumbar segments in the neonatal mouse, the axons spread among more segments. Recently, Xu et al. (2005) described a progressive focusing of recurrent inhibition such that its intersegmental spread becomes restricted with development in chick embryos. The mechanisms responsible for this restriction are not known.

Recently, it was shown that some neonatal motoneurons receive monosynaptic input from other motoneurons (Mentis et al., 2005; Nishimaru et al., 2005). It is unlikely that our sample included motoneurons in which antidromic impulses failed to invade the somatic compartment. We routinely stimulated three adjacent ventral roots, thereby minimizing the possibility that the root carrying the motor axon was not stimulated. Moreover, all neurons included in the sample are likely small interneurons because their input impedances were significantly larger than those of motoneurons recorded in the same preparation. The input resistances in our sample of Renshaw cells ranged from 187.8 to $1424.8 \mathrm{M} \Omega$ (average \pm SEM, $507.9 \pm 60.5 ; n=19$ ). By comparison, the values measured in antidromically identified motoneurons averaged $43.4 \pm 5.9 \mathrm{M} \Omega(n=14)$. There was no overlap in the distribution of input resistances between both groups of cells. Finally, all dye-labeled recorded interneurons had a morphology and location resembling Renshaw cells.

\section{Neonatal Renshaw cells receive glutamatergic monosynaptic inputs from dorsal roots}

Nineteen identified Renshaw cells were maintained at a resting potential more negative than $-45 \mathrm{mV}$ (mean $\pm \mathrm{SD},-52.4 \pm 4.5$ $\mathrm{mV}$; range, -46.1 to $-65.2 \mathrm{mV}$ ), and, of these, 12 (one $\mathrm{P} 2,10 \mathrm{P} 3$, and one $\mathrm{P} 4$ ) were recorded in preparations with robust dorsal root-evoked monosynaptic potentials in the homonymous ventral root. All but one of the 12 displayed a short-latency response (4.7-7.3 ms) to dorsal root stimulation. In L4/L5 Renshaw cells, stimulation of the ipsilateral homonymous dorsal root (dr-L4 or dr-L5) resulted in a depolarizing EPSP that was graded in amplitude in response to changes of stimulus intensity (Fig. 5C). In three L5 Renshaw cells, short-latency responses were also recorded when the adjacent (L4 or L6) dorsal roots were tested. In addition, one upper lumbar Renshaw cell (L1; $n=1)$ exhibited short-latency synaptic potentials in response to ipsilateral dorsal root input from the same or adjacent segments. Suprathreshold stimuli of the dorsal roots reliably evoked firing in Renshaw cells. Stimulation at two times threshold evoked short-latency responses (4.7-7.3 ms) in all P2-P4 Renshaw cells except one ( $\sim 92 \%$ of cells). One P3 Renshaw cell exhibited only longlatency $(12.8 \mathrm{~ms})$ responses during dorsal root stimulation and was excluded from the short-latency response analyses shown in Figure 6C.

The onset of the short-latency potentials recorded in Renshaw cells coincided with the onset of the monosynaptic reflex recorded simultaneously in the ventral roots (Fig. 6A). Shortlatency responses were stable at different stimulation frequencies $(0.1-5 \mathrm{~Hz}$ ) (Fig. 6B,C) at intensities two times threshold (Fig. $6 C$ ) (mean \pm SEM, $6.31 \pm 0.27 \mathrm{~ms}$ ) and had similar latencies to monosynaptic EPSPs recorded intracellularly from motoneurons in the same segment (Fig. $6 D, E)(6.54 \pm 0.77 \mathrm{~ms}, n=5 \mathrm{~L} 5$ Renshaw cells; and $6.98 \pm 0.81 \mathrm{~ms}, n=5$ L5 motoneurons; $p>$ $0.05, t$ test). Collectively, these properties suggest that shortlatency dorsal root responses recorded in Renshaw cells are 

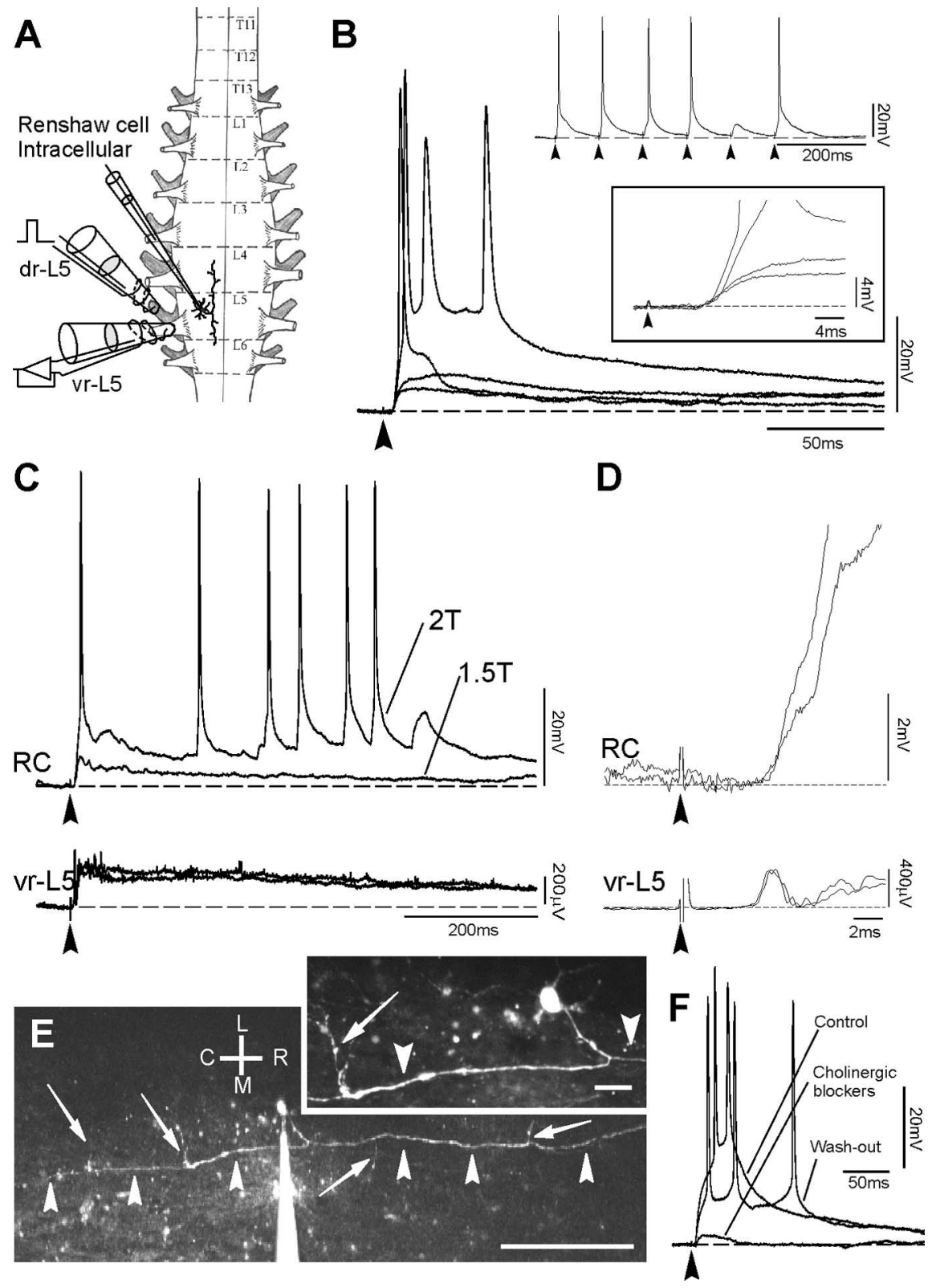

Figure 5. Renshaw cells receive synaptic inputs from ventral root motor axon collaterals and dorsal root sensory primary afferents. $\boldsymbol{A}_{\boldsymbol{t}}$ Schematic showing the experimental in vitro setup and the position of suction electrodes for recording and/or stimulating lumbar spinal roots in the isolated spinal cord of neonatal mice (P2-P4). Synaptic potentials in Renshaw cells were recorded whole cell in current clamp using patch electrodes. $\boldsymbol{B}$, Ventral root stimuli of different intensities evoked graded short-latency synaptic potentials (bottom record) in Renshaw cells. Action potentials were superimposed at the higher stimulus intensities. Boxed inset in $\boldsymbol{B}$ demonstrates the short-latency Renshaw cell response time locked to ventral root stimuli of different intensities (arrowhead indicates the stimulus artifact). The top right inset shows the Renshaw cell response to high-frequency stimulation (10 Hz) of the lumbar root at suprathreshold levels. On the fifth stimulus, the action potential failed revealing a subthreshold synaptic potential. C, Renshaw cell (RC) and extracellular ventral root (vr-L5) responses to ipsilateral dorsal root (dr-L5) stimuli. Threshold was defined as the stimulus intensity evoking a response (monosynaptic or polysynaptic) in three of five trials. Action potentials were evoked at stimulus intensities two times threshold. Responses to dorsal root stimuli were long and likely included polysynaptic components in the later part of the response. $\boldsymbol{D}$, Time-expanded responses from $\boldsymbol{C}$. Arrowheads in $\boldsymbol{C}$ and $\boldsymbol{D}$ show stimuli artifacts. The onset of the first responses in Renshaw cells coincides with the monosynaptic reflex recorded in the ventral root. $\boldsymbol{E}$, Two-photon confocal image of a Renshaw cell obtained during intracellular recording. The cell was labeled by intracellular injection with Alexa Fluor 488 hydrazide. The image is a projection of 20 optical planes in the $z$-axis each separated by 4.7 $\mu \mathrm{m}$ (total distance scanned, $89.4 \mu \mathrm{m}$ ). The cell soma was $\sim 80 \mu \mathrm{m}$ below the ventral surface of the cord. The axon of the cell projected rostrocaudally in the ventral funiculus (arrowheads), giving rise to collaterals (arrows) that enter the motor column and that can be seen moreclearly in the inset (insetimage acquired after electrode withdrawal; 2 p projection from 45 optical planes in thez-axis, each separated by $1.3 \mu \mathrm{m}$; total distance scanned, $58.5 \mu \mathrm{m}$ ). The axon could be followed over three segments. $R$, Rostral; $C$, caudal; L, lateral; $M$, medial. F, Superimposed suprathreshold potentials evoked by vr-L5 stimulation and recorded from a Renshaw cell, under control conditions, after application of cholinergic receptor antagonists (mecamylamine at $50 \mu \mathrm{m}, \mathrm{dH} \beta \mathrm{E}$ at $50 \mu \mathrm{m}$, and atropine at $5 \mu \mathrm{M}$ ) and after washout. The ventral root-evoked synaptic potential was greatly reduced, but not fully abolished, by cholinergic blockers (Mentis et al., 2005). The pharmacology of dorsal root responses are shown in Figure 4 . Scale bars: $E, 200 \mu \mathrm{m}$; inset, $20 \mu \mathrm{m}$. monosynaptic. The decay of dorsal rootevoked depolarizations was slow and of longer duration than ventral root-evoked responses, suggesting the presence of polysynaptic components in the tail of dorsal root-evoked EPSPs.

We found that bath application of glutamate receptor antagonists (APV at 100 $\mu \mathrm{M}$ and CNQX at $10 \mu \mathrm{M}$ ) reversibly abolished the dorsal root-evoked potentials recorded in Renshaw cells and ventral roots (Fig. $7 A, B$ ). After washout, $70-90 \%$ of the response was recovered. Cholinergic blockers (mecamylamine, atropine, and $\mathrm{dH} \beta \mathrm{E}$ ) applied to these recovered responses did not alter the latency or amplitude of the initial Renshaw cell response to dorsal root stimulation (Fig. 7C). Thus, it is unlikely that the early part of the dorsal root-evoked potential in Renshaw cells is contaminated by disynaptic excitatory inputs from motoneurons excited by dorsal root afferents.

In conclusion, neonatal Renshaw cells receive functional monosynaptic glutamatergic synaptic inputs capable of reliably evoking firing in these cells.

Adult VGLUT1 synapses on Renshaw cells dendrites are ultrastructurally less mature than other VGLUT1 synapses

In contrast to neonates, dorsal root afferents do not evoke firing in adult Renshaw cells (see Discussion). A reduced density of this input in adult (as shown above) might account for its "functional" deselection. In addition, individual synapses might be weakened. Unfortunately, it is not yet feasible to perform intracellular electrophysiological recordings in adult Renshaw cells to investigate changes in synaptic strength from dorsal root inputs. Therefore, we used alternatively an anatomical approach. It is known that synapse weakening is accompanied by a gradual decrease in presynaptic bouton size, the removal of presynaptic active zones, and the loss of postsynaptic receptors at sites with vacated or weak synapses (Lichtman and Colman, 2000; Walsh and Lichtman, 2003). At Ia afferent synapses, the size of presynaptic boutons and PSDs have been correlated with synapse release properties and synaptic strength (Pierce and Mendell, 1993). To gain additional insights into possible changes in strength of VGLUT1-IR synapses, we analyzed ultrastructurally VGLUT1-IR synaptic boutons and their associated postsynaptic densities in P15, P20, and adult Renshaw cell calbindin-IR dendrites and compared them with similar synapses over large dendrites in LIX that likely belong to motoneurons. 
We used preembedding electron microscopy dual immunolabeling to reveal VGLUT1 immunoreactivity with ABCperoxidase and calbindin-IR with immunogold silver (Fig. 8). P15, P20, and adult VGLUT1-IR boutons contacting calbindin-IR dendrites (and a few somata) were randomly sampled in the ventralmost regions of LVII and LIX. Appositions between VGLUT1-IR terminals and noncalbindin-IR dendrites (and a few somata) at the same ages in the adjacent neuropil were also imaged. Analyses were restricted to tissue depths showing abundant immunolabeling for both markers.

We measured bouton area, perimeter, and length of apposition between presynaptic and postsynaptic membranes and PSD length and numbers. Most VGLUT1-IR boutons displayed identifiable synaptic regions (Fig. $8 A-H$ ). The percentage of VGLUT1-IR boutons with at least one synapse over calbindin-IR or non-calbindin-IR dendrites were, respectively, $81.8 \%(n=26)$ and $78.6 \%(n=85)$ at $\mathrm{P} 15,87.5 \%(n=22)$ and $93.2 \%(n=55)$ at $\mathrm{P} 20$, and $74.1 \%(n=22)$ and $91.8 \%$ $(n=56)$ in the adult. Considering that only one random cross section per bouton was analyzed, these high percentages suggest a high number of synaptic sites per bouton.

The length of apposition between VGLUT1-IR bouton membranes and postsynaptic membranes on noncalbindin-IR dendrites increased significantly from P15 to P20 and adult [ \pm SEM, $1.84 \pm 0.08 \mu \mathrm{m}$ at P15 $(n=85)$ compared with $2.57 \pm 0.16 \mu \mathrm{m}$ at $\mathrm{P} 20(n=55)$ and $2.61 \pm 0.19 \mu \mathrm{m}$ in adult $(n=56)$; one-way ANOVA, $p<0.05]$. This was accompanied by a significant increase in bouton size estimated by their cross-sectional area (2.29 $\pm 0.14 \mu \mathrm{m}^{2}$ at P15 compared with $3.25 \pm 0.26 \mu \mathrm{m}^{2}$ at $\mathrm{P} 20$ and $2.93 \pm 0.22$ $\mu \mathrm{m}^{2}$ in adult; one-way ANOVA, $\left.p<0.05\right)$. In contrast, VGLUT1-IR boutons contacting calbindin-IR dendrites did not significantly increase in length of apposition $[1.70 \pm 0.17 \mu \mathrm{m}$ at $\mathrm{P} 15(n=33)$ compared with $1.95 \pm 0.21 \mu \mathrm{m}$ at P20 $(n=24)$ and $1.70 \pm 0.14 \mu \mathrm{m}$ in adult $(n=27)$; one-way ANOVA, $p=0.52)$ or bouton cross-sectional area $\left(1.78 \pm 0.25 \mu \mathrm{m}^{2}\right.$ at P15 compared with $2.18 \pm 0.32 \mu \mathrm{m}^{2}$ at $\mathrm{P} 20$ and $2.77 \pm 0.45 \mu \mathrm{m}^{2}$ in adult; one-way ANOVA, $p=0.13$ ). Some VGLUT1-IR boutons on Renshaw cell calbindin-IR dendrites were very large, but these were usually "glomerular" type and established synapses with a number of different postsynaptic targets. The inclusion of these larger boutons in the sample explains the trend toward increased areas and their larger variability. We can conclude that VGLUT1-IR boutons contacting Renshaw cell dendrites did not grow in size at the same rate than VGLUT1-IR synapses on noncalbindin-IR dendrites in LIX. This could suggest differential developmental strengthening of VGLUT1-IR synapses depending on their targets.

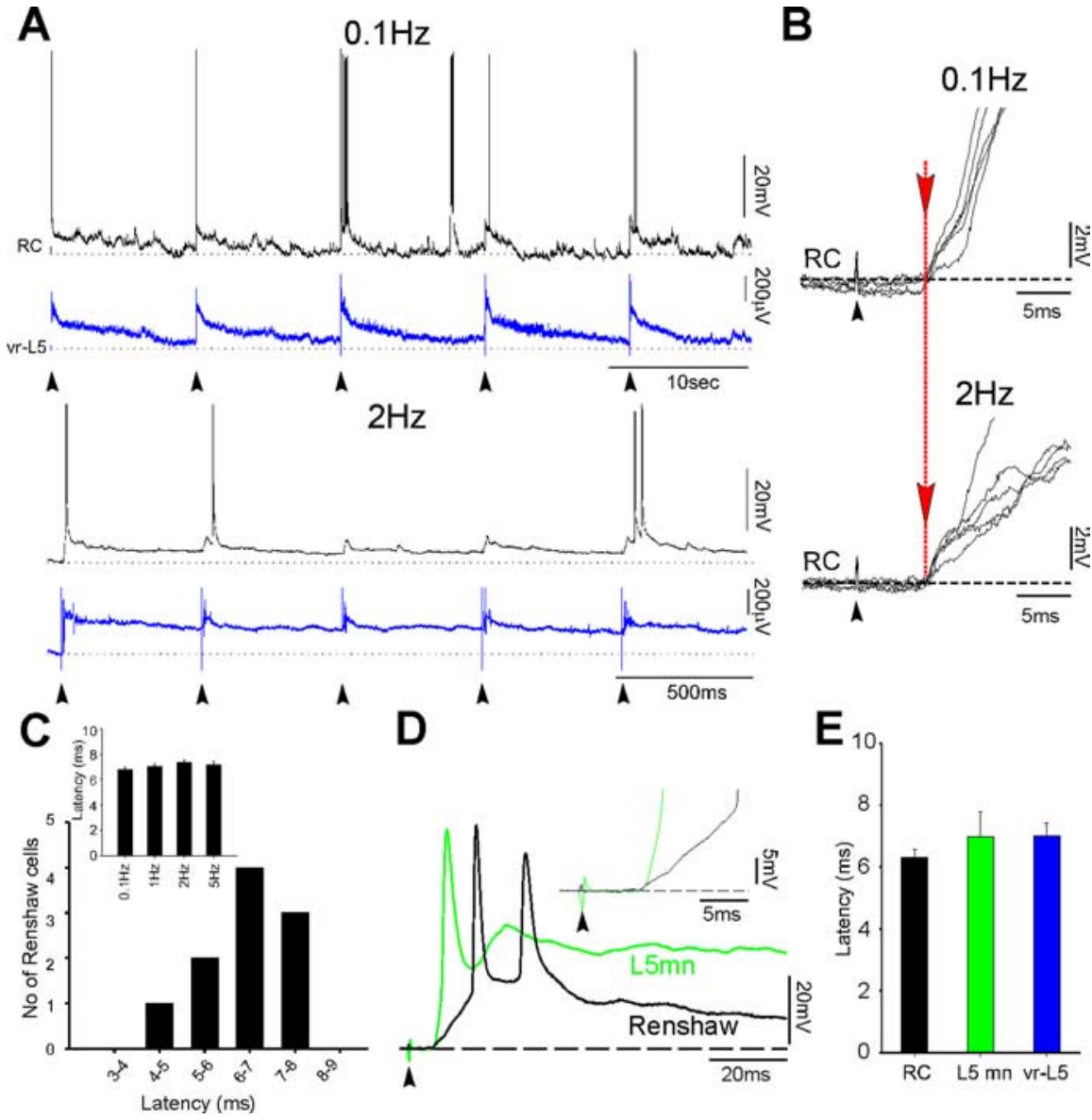

Figure 6. Dorsal root afferents evoke monosynaptic responses in Renshaw cells. $\boldsymbol{A}$, Responses from a Renshaw cell (RC, top traces in black) and the fifth ventral root ( $\mathrm{vr}-\mathrm{L} 5$, bottom traces in blue) to different stimulation frequencies of the ipsilateral dorsa latencies (red arrowheads point to the responses onset in several superimposed traces at each stimulation frequencies). $C_{-}$

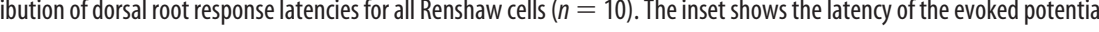
observed ( $p>0.05$, one-way ANOVA). D Comparison of synaptic responses from a motoneuron (green) and a Renshaw cell (black) to a single dr-L5 stimulus at suprathreshold intensity. The cells were not recorded simultaneously. Both neurons responded robustly and fired action potentials superimposed on the EPSPs. Inset shows the same latency for motoneuron and Renshaw cell responses to sensory inputs. $\boldsymbol{E}$, Comparison of average latencies for Renshaw cells (black; $n=10$ ), L5 motoneurons (green; $n=$ 5), and the ventral root $L 5$ (blue; $n=4$ ) extracellular recording after stimulation of the dorsal root $L 5$ (age range, P2-P3). There were no significant differences in the latencies among these groups ( $p>0.05$, one-way ANOVA). Error bars indicate SEM.

Moreover, we also found that the sizes of PSDs at VGLUT-IR synapses on calbindin-IR dendrites were significantly smaller than on non-calbindin-IR dendrites in the adult (respectively, $0.30 \pm 0.02$ and $0.41 \pm 0.02 \mu \mathrm{m}$ lengths; $p<0.05, t$ test). These were the consequence of a developmental reduction in PSD size specifically in VGLUT1-IR synapses over calbindin-IR Renshaw cells (Fig. 8, compare $C, D, G-I$ ) (one-way ANOVA, $p<0.05$ ). Similarly, the number of PSDs/active zones per bouton increased from P15 to P20 and adult for VGLUT1-IR boutons on noncalbindin-IR targets but did not change for VGLUT1-IR synapses on calbindin-IR Renshaw cell dendrites (Fig. 8J). Smaller PSD sizes and the lack of increase in PSD number per bouton resulted in large differences in the total amount of PSD length per bouton apposition in P20/adults when comparing VGLUT1-IR synapses on calbindin-IR and non-calbindin-IR dendrites (Fig. $8 \mathrm{~K}$ ). Presynaptic active zone structure was obscured by DAB precipitate but is known to mirror PSD extension and structure (Pierce and 


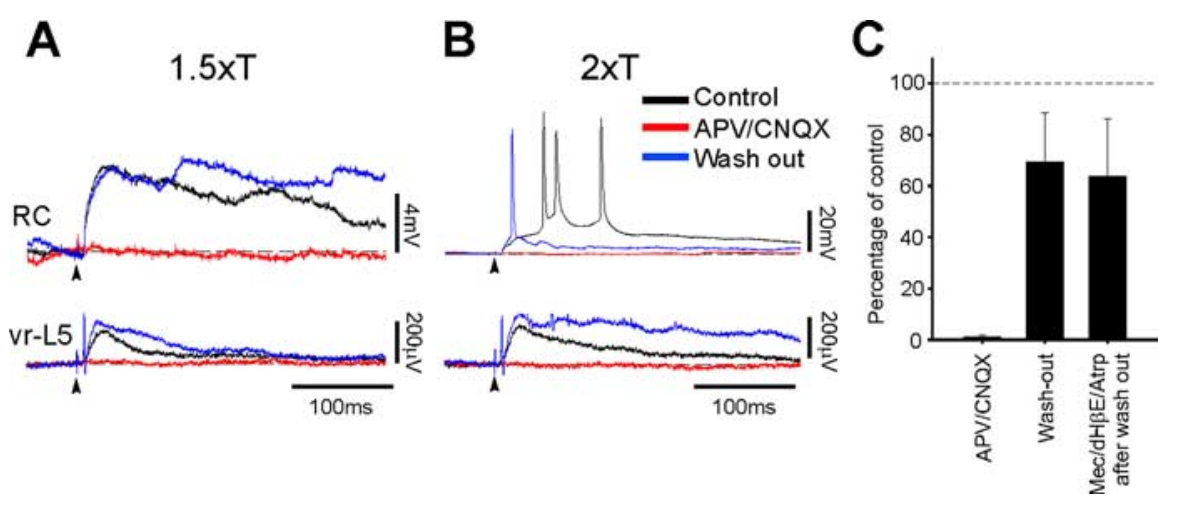

Figure 7. Dorsal root-evoked potentials in Renshaw cells are glutamatergic. $A$, Superimposition of control responses (black traces) of a Renshaw cell (RC) and the $L 5$ ventral root (vr-L5) after stimulation of the $L 5$ dorsal root at $1.5 \times$ threshold $(1.5 \times T)$. Red traces show the responses after 20 min superfusion with APV (100 $\mu \mathrm{M})$ and CNQX (10 $\mu \mathrm{m})$ (red traces). Blue traces are the responses after 40 min washout. Renshaw cells and vr-L5 responses were fully abolished during block of NMDA and AMPA receptors. $\boldsymbol{B}$, Renshaw cell (intracellular) and vr- $\mathrm{L} 5$ extracellular responses after dorsal root suprathreshold stimulation $(2 \times \mathrm{T})$ were also blocked by the APV/CNQX mixture and recovered after 40 min of washout. $C$, Percentage change in the peak amplitude of Renshaw cell dorsal root-evoked synaptic potentials in three cells normalized to the control amplitude (subthreshold stimulation to avoid action potentials). The cholinergic receptor antagonists (mecamylamine at $50 \mu \mathrm{M}, \mathrm{dH} \beta \mathrm{E}$ at $50 \mu \mathrm{m}$, and atropine at $5 \mu \mathrm{m}$ ) had no significant effect on the dorsal root-evoked potentials.

Mendell, 1993); thus, it is likely that presynaptic active zones (release sites) show parallel differences in number and size.

The ultrastructural data suggest a differential maturation of VGLUT1-IR synapses in the ventral horn, likely resulting in functional weakening on calbindin-IR Renshaw cell dendrites and strengthening on other postsynaptic targets.

\section{Discussion}

In this manuscript, we show that Renshaw cells in rats and mice receive a functionally significant monosynaptic primary afferent input during early development. Based on the ventral location of Renshaw cells, we conclude that dorsal root synapses are most likely Ia afferents (Brown, 1981; Fyffe, 1984). The morphological data also suggest that putative Ia synapses are maintained, at least structurally, on adult Renshaw cells. This input does not appear to be species specific because it was present in rats, mice, and cats.

These observations challenge the generally accepted view, derived from electrophysiological studies in the cat spinal cord, that Renshaw cells lack monosynaptic sensory inputs. Renshaw's original description (1946) indicated that these interneurons did not respond to dorsal root volleys that excited just "a few" motoneurons. However, in some instances, larger stimuli could elicit firing. Whether these responses were monosynaptic or polysynaptic was not addressed. Monosynaptic dorsal root activation of Renshaw cells (responses evoked with latencies $<1 \mathrm{~ms}$ ) was later proposed by Frank and Fuortes (1956) in decerebrated cats. However, subsequent work using barbiturate- or chloraloseanesthetized cats failed to find monosynaptic connections (Curtis and Ryall, 1966; Ryall and Piercey, 1971; Ryall et al., 1972). These latter studies suggested that Ia afferent inputs do influence Renshaw cell activity but via disynaptic (through motoneurons) or polysynaptic pathways. However, the authors also carefully indicated that weak monosynaptic excitation could not be completely ruled out. Other work indicated that adult Renshaw cells receive polysynaptic excitation from ipsilateral group II and III muscle and cutaneous afferents (for review, see Baldissera et al., 1981). Monosynaptic connections from these afferents would be unlikely because they do not project (Brown, 1981; Fyffe, 1984) to ventral spinal cord regions containing Renshaw cell dendrites
(Jankowska and Lindstrom, 1971; Lagerback and Kellerth, 1985; Alvarez et al., 1997; Bui et al., 2003).

Related anatomical work has been rather scant, but one electron microscopy study (Lagerback and Ronnevi, 1982) described synapses on cat Renshaw cells that received presynaptic axo-axonic control and were ultrastructurally similar to Ia afferent synapses on motoneurons (Conradi et al., 1983; Fyffe and Light, 1984; Pierce and Mendell, 1993).

Physiological studies of Renshaw cell connectivity in the developing cat are obviously difficult technically. Nevertheless, in one remarkable study, intracellular recordings were obtained from presumed Renshaw cells in the cat fetus (Naka, 1964). It was found that stimulation of dorsal roots could evoke Renshaw cell firing. Although the author suggested that the effect was mediated disynaptically via motoneuron collaterals, it could also reflect a monosynaptic excitation similar to that described here. If so, it raises the possibility that functional monosynaptic connections exist between dorsal root afferents and Renshaw cells in the cat fetus that become silenced in adult.

\section{Postnatal development of dorsal root synapses on Renshaw cells}

We found that dorsal root inputs are comparatively rare on embryonic Renshaw cells, but they proliferate during the first postnatal week and contact all Renshaw cells by the second postnatal week. This time course is slightly delayed compared with the development of Ia-motoneuron synaptic connections (Kudo and Yamada, 1987; Snider et al., 1992) (for review, see Chen and Frank, 1999). One possible explanation for this delay is that Ia afferent axons have to project significantly farther ventral to contact Renshaw cell dendrites than motoneuron dendrites. Dorsal root varicosities contacting embryonic Renshaw cells (or motoneurons) lack detectable VGLUT1 immunoreactivity, suggesting a very immature synapse or perhaps a different release mechanism. VGLUT1-IR vesicle clusters appear at P0 and significantly mature during the first 2 postnatal weeks. VGLUT1 content thus parallels changes in synaptic release properties described at Iamotoneuron connections (Kudo and Yamada, 1987; Seebach and Mendell, 1996; Mears and Frank, 1997; Li and Burke, 2002).

Sensory inputs evoked robust firing in neonatal Renshaw cells, but several lines of evidence suggest that the strength of dorsal root inputs onto Renshaw cells decreases with maturation. First, although the number of VGLUT1-IR dorsal root synapses changes little with development, their density is significantly reduced from P15 to adult as a consequence of the growth of the Renshaw cell dendritic arbor. Second, Renshaw cell input resistance decreases significantly with postnatal development (D. Gonzalez-Forero and F. J. Alvarez, unpublished observations), and powerful mixed GABAergic/glycinergic inhibitory synapses develop on the soma and most proximal dendrites (Geiman et al., 2000, 2002; Gonzalez-Forero and Alvarez, 2005). Both of these factors likely reduce the amplitude of dorsal root-evoked synaptic potentials at the cell body of Renshaw cells and their influence on Renshaw cell firing. Moreover, individual VGLUT1-IR synapses 
on Renshaw cells fail to enlarge and mature after P15, in contrast to the growth of such synapses on non-Renshaw dendrites. If as suggested (Pierce and Mendell, 1993; Pierce and Lewin, 1994), Ia afferent bouton sizes correlate with synaptic strength, this morphological result could indicate arrested maturation or even decreased synaptic efficacy of VGLUT1-IR synapses on Renshaw cells during late postnatal development and into adulthood. A reduction in the size of synaptic active zones and PSDs are characteristic of synapses in the process of elimination (Rich and Lichtman, 1989; Balice-Gordon and Lichtman, 1993; Colman et al., 1997; Culican et al., 1998). Although dorsal root synapses on Renshaw cells are not withdrawn, it is possible that mechanisms engaged in synapse elimination might also act to limit synaptic maturation and thereby result in reduced functional efficacy. These findings and the fact that VGLUT1-IR boutons are present on adult cat Renshaw cells, in which dorsal root inputs have been difficult to demonstrate in previous physiological studies, raises the possibility that sensory synapses on adult Renshaw cells might be functionally silent. This could occur because of a very low probability of transmitter release, low transmitter concentration in the synaptic cleft, or absent or reduced postsynaptic receptors (Voronin and Cherubini, 2004). In future experiments, it will be important to examine these synapses in the adult animal and establish whether they can be made functional by stimulation paradigms that have been shown to enhance synaptic function in other parts of the nervous system.

In contrast to dorsal root synapses, cholinergic motor inputs on developing Renshaw cells continued to proliferate and are known to remain functionally significant in the adult. The development of inhibitory synapses on Renshaw cells is in part dependent on motor axon synaptic activity (Gonzalez-Forero et al., 2005). If inhibitory drive contributes to suppress dorsal root synapses, then motor axon inputs could have a central role in determining (directly or indirectly) overall synaptic organization on Renshaw cells. Inhibitory modulation might also explain previous controversies on the efficacy of dorsal root inputs on adult cat Renshaw cells obtained from decerebrated animals compared with animals under anesthesia regimens that increase inhibitory drive (see above).

\section{Diversification of V1-derived inhibitory interneurons}

The V1 embryonic interneuronal group gives rise to neurons with ipsilaterally projecting axons that establish inhibitory synapses with motoneurons (Matise and Joyner, 1997; Saueressig et
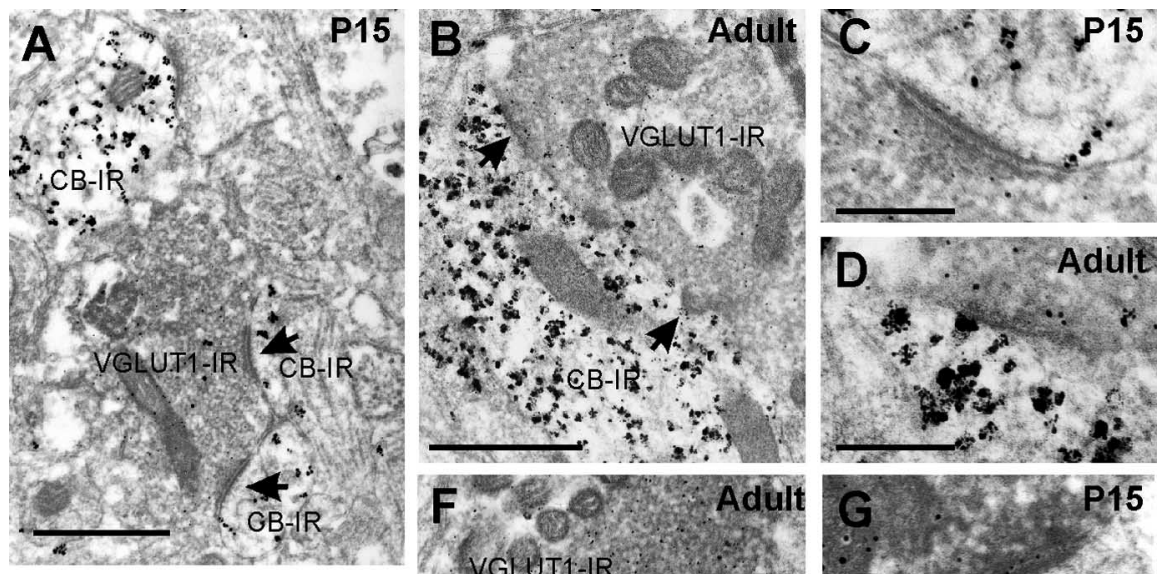

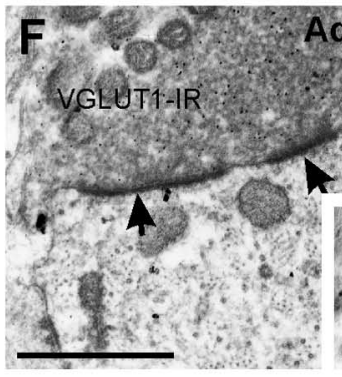

J Average PSD number per bouton
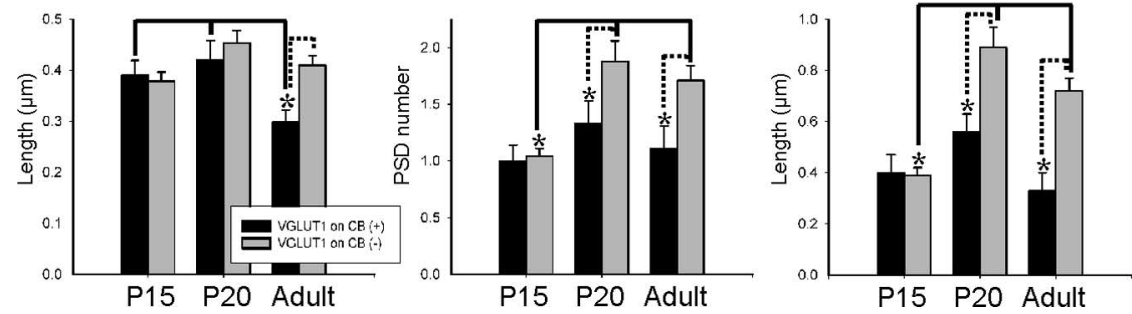

Figure 8. Ultrastructural morphology of VGLUT1-IR boutons on calbindin-IR and non calbindin-IR dendrites. A, VGLUT1-IR bouton (silver-intensified DAB; electron-dense diffuse reaction product covered by a fine silver precipitate) from a P15 spinal cord in synaptic contact (arrows) with two calbindin-IR dendrites (CB-IR; immunogold silver; large and irregular particles). Above, another calbindin-IR dendrite (CB-IR) receives an excitatory synapse (asymmetric with round vesicles) from a non-VGLUT1-IR terminal. $\boldsymbol{B}$, VGLUT1-IR bouton in synaptic contact with a calbindin-IR dendrite in the adult. This bouton makes two small synapses with the dendrite (arrows). $\boldsymbol{C}$ and $\boldsymbol{D}$ show high-magnification images of the synapses indicated by the bottom arrow in $\boldsymbol{A}$ and by the top arrow in $\boldsymbol{B}$, respectively. Notice that the PSD in the adult synapse is smaller and less electron-dense than the one in the P15 synapse. $\boldsymbol{E}$, VGLUT1-IR bouton making two synapses (arrows) with two different calbindin-immunonegative dendrites. $\boldsymbol{F}$ VGLUT1-IR bouton making two large synaptic contacts with a large caliber calbindin-negative dendrite in adult LIX region. $\mathbf{G}$ and $\boldsymbol{H}$ show at high magnification the synapses indicated by the bottom arrow in $\boldsymbol{E}$ and the left arrow in $\boldsymbol{F}$, respectively. Notice that P15 and adult synapses both display well formed and distinctively electron-dense PSDs. The size difference is representative of the range found in P15 and adult VGLUT1-IR synapses. On average, however, there were no differences in PSD size over noncalbindin-IR synapses at any age. Images from P20 synapses are not shown but were included in the quantitative study. I,

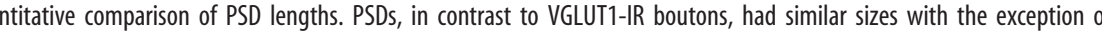
VGLUT1-IR boutons on adult calbindin-IR dendrites. A significant reduction in size was observed compared with all other VGLUT1-IR boutons of different ages or contacting non-calbindin-IR dendrites. J, The number of PSDs per bouton increased with bouton, and therefore integrates data from $/$ and $J$. Consequently, a large decrease on total PSD length was observed, presynaptic to calbindin-IR dendrites, whereas this same parameter increased from P15 to P20/adult for VGLUT1-IR boutons presynaptic to non-calbindin-IR dendrites. Scale bars: $\boldsymbol{A}, \boldsymbol{B}, \boldsymbol{E}, \boldsymbol{F}, 1 \mu \mathrm{m} ; \boldsymbol{C}, \boldsymbol{D}, \boldsymbol{G}, \boldsymbol{H}, 0.3 \mu \mathrm{m} .{ }^{*} p<0.05$.

al., 1999; Sapir et al., 2004; Alvarez et al., 2005). The first functional analysis of $\mathrm{V} 1$ interneurons in the chick suggested that they constitute a heterogeneous population (Wenner et al., 2000). Later studies in the mouse showed that Renshaw cells and IaINs are specifically derived from V1 interneurons (Sapir et al., 2004; Alvarez et al., 2005). V1 interneurons form a more homogeneous group in other vertebrates such as zebrafish and tadpoles (Higashijima et al., 2004; Li et al., 2004), but this group clearly diversifies into different populations in birds and mammals. Func- 
tional suppression or enhancement of certain inputs, as shown in here, could contribute to generate distinct synaptic organizations and interneuron diversity. Most V1-derived interneurons are located in spinal cord regions that receive abundant proprioceptive input (Alvarez et al., 2005). Our data suggest that early postnatal mammalian Renshaw cells receive dorsal root inputs similar to other V1-derived interneurons, and we hypothesize that this input is weakened in the late postnatal period. According to this idea, this mechanism would contribute to differentiate Renshaw cells from the V1 group as an interneuronal derivative that loses strong proprioceptive inputs while selecting a potent motor axon input.

The mechanisms responsible for the weakening of sensory inputs on Renshaw cells are unknown. It is possible, for example, that the proliferation of cholinergic inputs during the first 3 neonatal weeks might be causally related to this weakening. This could be investigated by establishing whether afferent inputs onto Renshaw cells are enhanced in mice deficient for VAChT (Prado et al., 2006). It is also possible that changes in afferent activity in the first 3 neonatal weeks could alter this input on Renshaw cells. Mice do not engage in weight-bearing locomotion until P10, so that a significant change in the activity of muscle afferents is inevitable after this age. Interestingly, the major deselection of afferent inputs onto Renshaw cells occurs shortly after weight-bearing locomotion has begun (P15). In this regard, it is worth emphasizing that many studies of locomotor-like activity use in vitro spinal cord preparations in the first neonatal week. Because significant changes in synaptic organization likely occur after the first and second neonatal week, caution should be observed in generalizing from such experiments in the adult.

\section{References}

Alvarez FJ, Dewey DE, Harrington DA, Fyffe RE (1997) Cell-type specific organization of glycine receptor clusters in the mammalian spinal cord. J Comp Neurol 379:150-170.

Alvarez FJ, Dewey DE, McMillin P, Fyffe RE (1999) Distribution of cholinergic contacts on Renshaw cells in the rat spinal cord: a light microscopic study. J Physiol (Lond) 515:787-797.

Alvarez FJ, Jonas PC, Sapir T, Hartley R, Berrocal MC, Geiman EJ, Todd AJ, Goulding M (2005) Postnatal phenotype and localization of spinal cord V1 derived interneurons. J Comp Neurol 493:177-192.

Arber S, Ladle DR, Lin JH, Frank E, Jessell TM (2000) ETS gene Er81 controls the formation of functional connections between group Ia sensory afferents and motor neurons. Cell 101:485-498.

Baldissera F, Hultborn H, Illert M (1981) Integration in spinal neural systems. In: Handbook of physiology. The nervous system, Vol II, Motor control, Pt I (Brooks VB, ed), pp 509-595. Bethesda: American Physiology Society.

Balice-Gordon RJ, Lichtman JW (1993) In vivo observations of pre- and postsynaptic changes during the transition from multiple to single innervation at developing neuromuscular junctions. J Neurosci 13:834-855.

Brown AG (1981) Organization of the spinal cord. The anatomy and physiology of identified neurons. New York: Springer.

Brown MC, Jansen JK, Van Essen D (1976) Polyneuronal innervation of skeletal muscle in new-born rats and its elimination during maturation. J Physiol (Lond) 261:387-422.

Bui TV, Cushing S, Dewey D, Fyffe RE, Rose PK (2003) Comparison of the morphological and electrotonic properties of Renshaw cells, Ia inhibitory interneurons, and motoneurons in the cat. J Neurophysiol 90:2900-2918.

Carr PA, Alvarez FJ, Leman EA, Fyffe RE (1998) Calbindin D28k expression in immunohistochemically identified Renshaw cells. NeuroReport 9:2657-2661.

Chen HH, Frank E (1999) Development and specification of muscle sensory neurons. Curr Opin Neurobiol 9:405-409.

Colman H, Nabekura J, Lichtman JW (1997) Alterations in synaptic strength preceding axon withdrawal. Science 275:356-361.

Conradi S, Cullheim S, Gollvik L, Kellerth JO (1983) Electron microscopic observations on the synaptic contacts of group Ia muscle spindle afferents in the cat lumbosacral spinal cord. Brain Res 265:31-39.

Crepel F, Mariani J, Delhaye-Bouchaud N (1976) Evidence for a multiple innervation of Purkinje cells by climbing fibers in the immature rat cerebellum. J Neurobiol 7:567-578.

Culican SM, Nelson CC, Lichtman JW (1998) Axon withdrawal during synapse elimination at the neuromuscular junction is accompanied by disassembly of the postsynaptic specialization and withdrawal of Schwann cell processes. J Neurosci 18:4953-4965.

Curtis DR, Ryall RW (1966) The synaptic excitation of Renshaw cells. Exp Brain Res 2:81-96.

Eccles JC, Fatt P, Koketsu K (1954) Cholinergic and inhibitory synapses in a pathway from motor-axon collaterals to motoneurones. J Physiol (Lond) 126:524-562.

Eccles JC, Fatt P, Landgren S (1956) Central pathway for direct inhibitory action of impulses in largest afferent nerve fibres to muscle. J Neurophysiol 19:75-98.

FitzSimons E, Van Zundert B, Constantine-Paton M, Brown Jr RH, Alvarez FJ (2006) Alterations in the Renshaw cell recurrent inhibitory circuit in the G93A SOD1 mouse model of ALS. Soc Neurosci Abstr 32:678.9.

Frank K, Fuortes MG (1956) Unitary activity of spinal interneurones of cats. J Physiol (Lond) 131:424-435.

Fyffe RE (1984) Afferent fibers. In: Handbook of the spinal cord. Vol 2 and 3, Anatomy and physiology (Davidoff RA, ed), pp 79-135. New York: Dekker.

Fyffe RE (1991) Spatial distribution of recurrent inhibitory synapses on spinal motoneurons in the cat. J Neurophysiol 65:1134-1149.

Fyffe RE, Light AR (1984) The ultrastructure of group Ia afferent fiber synapses in the lumbosacral spinal cord of the cat. Brain Res 300:201-209.

Geiman EJ, Knox MC, Alvarez FJ (2000) Postnatal maturation of gephyrin/ glycine receptor clusters on developing Renshaw cells. J Comp Neurol 426:130-142.

Geiman EJ, Zheng W, Fritschy JM, Alvarez FJ (2002) Glycine and GABA(A) receptor subunits on Renshaw cells: relationship with presynaptic neurotransmitters and postsynaptic gephyrin clusters. J Comp Neurol 444:275-289.

Gonzalez-Forero D, Alvarez FJ (2005) Differential postnatal maturation of GABAA, glycine receptor, and mixed synaptic currents in Renshaw cells and ventral spinal interneurons. J Neurosci 25:2010-2023.

Gonzalez-Forero D, Pastor AM, Geiman EJ, Benitez-Temino B, Alvarez FJ (2005) Regulation of gephyrin cluster size and inhibitory synaptic currents on Renshaw cells by motor axon excitatory inputs. J Neurosci 25:417-429.

Goulding M, Lanuza G, Sapir T, Narayan S (2002) The formation of sensorimotor circuits. Curr Opin Neurobiol 12:508-515.

Higashijima S, Masino MA, Mandel G, Fetcho JR (2004) Engrailed-1 expression marks a primitive class of inhibitory spinal interneuron. J Neurosci 24:5827-5839.

Jankowska E (1992) Interneuronal relay in spinal pathways from proprioceptors. Prog Neurobiol 38:335-378.

Jankowska E (2001) Spinal interneuronal systems: identification, multifunctional character and reconfigurations in mammals. J Physiol (Lond) 533:31-40.

Jankowska E, Lindstrom S (1971) Morphological identification of Renshaw cells. Acta Physiol Scand 81:428-430.

Jankowska E, Smith DO (1973) Antidromic activation of Renshaw cells and their axonal projections. Acta Physiol Scand 88:198-214.

Jessell TM (2000) Neuronal specification in the spinal cord: inductive signals and transcriptional codes. Nat Rev Genet 1:20-29.

Katz LC, Crowley JC (2002) Development of cortical circuits: lessons from ocular dominance columns. Nat Rev Neurosci 3:34-42.

Katz LC, Shatz CJ (1996) Synaptic activity and the construction of cortical circuits. Science 274:1133-1138.

Kim G, Kandler K (2003) Elimination and strengthening of glycinergic/ GABAergic connections during tonotopic map formation. Nat Neurosci 6:282-290.

Kudo N, Yamada T (1987) Morphological and physiological studies of development of the monosynaptic reflex pathway in the rat lumbar spinal cord. J Physiol (Lond) 389:441-459.

Lagerback PA, Kellerth JO (1985) Light microscopic observations on cat Renshaw cells after intracellular staining with horseradish peroxidase. II. The cell bodies and dendrites. J Comp Neurol 240:368-376. 
Lagerback PA, Ronnevi LO (1982) An ultrastructural study of serially sectioned Renshaw cells. II. Synaptic types. Brain Res 246:181-192.

Li WC, Higashijima S, Parry DM, Roberts A, Soffe SR (2004) Primitive roles for inhibitory interneurons in developing frog spinal cord. J Neurosci 24:5840-5848.

Li Y, Burke RE (2002) Developmental changes in short-term synaptic depression in the neonatal mouse spinal cord. J Neurophysiol 88:3218-3231.

Lichtman JW, Colman H (2000) Synapse elimination and indelible memory. Neuron 25:269-278.

Matise MP, Joyner AL (1997) Expression patterns of developmental control genes in normal and Engrailed-1 mutant mouse spinal cord reveal early diversity in developing interneurons. J Neurosci 17:7805-7816.

McCurdy ML, Hamm TM (1994) Spatial and temporal features of recurrent facilitation among motoneurons innervating synergistic muscles of the cat. J Neurophysiol 72:227-234.

Mears SC, Frank E (1997) Formation of specific monosynaptic connections between muscle spindle afferents and motoneurons in the mouse. J Neurosci 17:3128-3135.

Mentis GZ, Siembab VC, Zerda R, O’Donovan MJ, Alvarez FJ (2004) Murine Renshaw cells receive monosynaptic input from sensory afferents. Soc Neurosci Abstr 24:838.6.

Mentis GZ, Alvarez FJ, Bonnot A, Richards DS, Gonzalez-Forero D, Zerda R, O'Donovan MJ (2005) Noncholinergic excitatory actions of motoneurons in the neonatal mammalian spinal cord. Proc Natl Acad Sci USA 102:7344-7349.

Naka KI (1964) Electrophysiology of the fetal spinal cord. II. Interaction among peripheral inputs and recurrent inhibition. J Gen Physiol 47:1023-1038.

Nishimaru H, Restrepo CE, Ryge J, Yanagawa Y, Kiehn O (2005) Mammalian motor neurons corelease glutamate and acetylcholine at central synapses. Proc Natl Acad Sci USA 102:5245-5249.

Pierce JP, Lewin GR (1994) An ultrastructural size principle. Neuroscience 58:441-446.

Pierce JP, Mendell LM (1993) Quantitative ultrastructure of Ia boutons in the ventral horn: scaling and positional relationships. J Neurosci 13:4748-4763.

Prado VF, Martins-Silva C, de Castro BM, Lima RF, Barros DM, Amaral E, Ramsey AJ, Sotnikova TD, Ramirez MR, Kim HG, Rossato JI, Koenen J, Quan H, Cota VR, Moraes MF, Gomez MV, Guatimosim C, Wetsel WC, Kushmerick C, Pereira GS, et al. (2006) Mice deficient for the vesicular acetylcholine transporter are myasthenic and have deficits in object and social recognition. Neuron 51:601-612.
Renshaw B (1946) Central effects of centripetal impulses in axons of spinal central roots. J Neurophysiol 9:191-204.

Rich MM, Lichtman JW (1989) In vivo visualization of pre- and postsynaptic changes during synapse elimination in reinnervated mouse muscle. J Neurosci 9:1781-1805.

Ryall RW, Piercey MF (1971) Excitation and inhibition of Renshaw cells by impulses in peripheral afferent nerve fibers. J Neurophysiol 34:242-251.

Ryall RW, Piercey MF, Polosa C, Goldfarb J (1972) Excitation of Renshaw cells in relation to orthodromic and antidromic excitation of motoneurons. J Neurophysiol 35:137-148.

Sapir T, Geiman EJ, Wang Z, Velasquez T, Mitsui S, Yoshihara Y, Frank E, Alvarez FJ, Goulding M (2004) Pax6 and engrailed 1 regulate two distinct aspects of renshaw cell development. J Neurosci 24:1255-1264.

Sassoe-Pognetto M, Wassle H, Grunert U (1994) Glycinergic synapses in the rod pathway of the rat retina: cone bipolar cells express the $\alpha 1$ subunit of the glycine receptor. J Neurosci 14:5131-5146.

Saueressig H, Burrill J, Goulding M (1999) Engrailed-1 and netrin-1 regulate axon pathfinding by association interneurons that project to motor neurons. Development 126:4201-4212.

Seebach BS, Mendell LM (1996) Maturation in properties of motoneurons and their segmental input in the neonatal rat. J Neurophysiol 76:3875-3885.

Shatz CJ (1983) The prenatal development of the cat's retinogeniculate pathway. J Neurosci 3:482-499.

Snider WD, Zhang L, Yusoof S, Gorukanti N, Tsering C (1992) Interactions between dorsal root axons and their target motor neurons in developing mammalian spinal cord. J Neurosci 12:3494-3508.

van Keulen LC (1979) Axon trajectories of Renshaw cells in the lumbar spinal cord of the cat, as reconstructed after intracellular staining with horseradish peroxidase. Brain Res 167:157-162.

Voronin LL, Cherubini E (2004) "Deaf, mute and whispering" silent synapses: their role in synaptic plasticity. J Physiol (Lond) 557:3-12.

Walsh MK, Lichtman JW (2003) In vivo time-lapse imaging of synaptic takeover associated with naturally occurring synapse elimination. Neuron 37:67-73.

Wenner P, O’Donovan MJ (1999) Identification of an interneuronal population that mediates recurrent inhibition of motoneurons in the developing chick spinal cord. J Neurosci 19:7557-7567.

Wenner P, O’Donovan MJ, Matise MP (2000) Topographical and physiological characterization of interneurons that express engrailed- 1 in the embryonic chick spinal cord. J Neurophysiol 84:2651-2657.

Xu H, Whelan PJ, Wenner P (2005) Development of an inhibitory interneuronal circuit in the embryonic spinal cord. J Neurophysiol 93:2922-2933. 